\title{
The effects of ownership identity on corporate diversification strategy of Chinese companies in foreign markets
}

\begin{abstract}
In this paper, we examine the impact of acquirer's ownership identity on corporate diversification decisions of Chinese companies in their cross-border acquisitions. Few studies to date have looked at the effect of ownership on corporate decisions to diversify abroad, particularly in the emerging market context. We find that certain characteristics of acquirer's ownership identity such as the government ownership, business group membership and being publicly traded will be negatively linked with industry diversification in international markets. Also, the effects of ownership identities are contingent upon the host country selection, and acquisitions into developed host countries are likely to be in unrelated industries. We observe that Chinese companies that buy in developed markets engage in global consolidation. These results support our arguments on domestic market protection strategies adopted by the Chinese companies for mitigating competition from their developed market rivals.
\end{abstract}

Keywords: Outward investment, China, Government Ownership, Business Group, Industry diversification, Developed country acquisitions 


\section{Introduction}

Chinese multinational enterprises (CMNEs) have used cross-border acquisitions as a strategic tool to enter foreign markets (Buckley, Yu, Liu, Munjal \& Tao, 2016a; Chen \& Young, 2010; Cui \& Jiang, 2012; Erdener \& Shapiro, 2005; Huang \& Renyong, 2014; Nicholson \& Salaber, 2013) as well as have used this process to diversify into other industries (Lu, Liu \& Wang, 2011; Ramamurti, 2008). However, few studies have looked at the decision of industrial diversification in an international context for CMNEs. Industrial diversification implies that firms will target firms belonging to industry different to their own, and in this paper, it means CMNEs are buying unrelated targets in a different industry to theirs in the foreign markets. For example, Haier's acquisition of GE Appliances is a related acquisition as they are in the same industry, whereas, property giant Wanda's acquisition of Legendary Entertainment production company is a case of industrial diversification in the foreign markets as they are in an unrelated line of business. Industrial diversification in a foreign country will require major commitments as it will require an overhaul of current corporate strategies to reap the potential benefits. Otherwise, potential synergy is limited at best due to the cross-country differences and costs of international diversification (Tallman \& Li, 1996). Entering unrelated industry abroad is extremely risky when firms do not have enough experience to deal with the liability of foreignness in the host country and liability of newness in the new industry ( $\mathrm{Lu} \&$ Beamish, 2004). Firm characteristics may play a role here. To be specific, corporate ownership has been recognized as a considerable impact on internationalization (Oesterle, Richta \& Fisch, 2013). Therefore, internationalization and diversification strategies are largely influenced by firm ownership characteristics. So, we argue that most prior studies examining corporate diversification strategies do not consider the overall effect of home and host institutional environments and typology of heterogeneity of different types of firms that are making these decisions. Therefore, in this paper, we will build up a theoretical framework on how ownership identities of firms might determine the choice of industry diversification abroad. To be specific, we will examine the impact of ownership identities on CMNEs industrial diversification in cross-border acquisitions.

The home country institutional environment we choose to focus on, i.e., China is an emerging market. These firms from China face several challenges when they are investing and expanding their business operations. Also, CMNEs are deeply embedded in their institutional environment, and they usually have limited experience in international activities (Chen \& Young, 2010; Child \& Marinova, 2014). To avoid excessive risk, some companies may decide to enter a foreign country, or a different industry step by step by leveraging their business 
networks and incremental knowledge of foreign markets, and they are less likely to combine both international diversification and industrial diversification strategies (Meyer \& Thaijongrak, 2013). Thus, the home country context offers an excellent opportunity to examine the strategic choices of industry relatedness in a foreign country. We argue that for Chinese firms entering an unrelated industry in the foreign market may be a particularly challenging decision that is not necessarily beneficial for the company. On the contrary, entering the same sector in foreign markets not only facilitates potential growth but also offers synergy in critical strategic assets (Rui \& Yip, 2008).

The role of corporate ownership identities is especially relevant in the context of China because institutional voids in home countries would lead to the importance of monitoring at the firm-level (Choi, Yoshikawa, Zahra \& Han, 2014). Thus, some ownership identities (such as business group, State-Owned Enterprises (SOEs)) that are not common in advanced countries are typical in China. It is important to note that in the original framework of Luo, and Tung (2007) on cross-border acquisitions, they excluded SOEs. So, the heterogeneity among different types of Chinese firms has not been extensively explored. We focus on whether ownership identities such as government ownership, membership of a business group, and publicly-listed status will impact the industry diversification strategy of the Chinese companies in foreign markets.

To fill in the research gap on CMNEs' cross-border industry diversification, we will focus on a sample of mainland Chinese firms acquiring targets in developed and developing countries. We also examine whether the ownership characteristics of the acquiring firms could potentially explain the Chinese acquisitions beyond their core sectors. We find that the government ownership has a negative impact on the firm's tendency to diversify abroad. We also observe similar results for companies that are part of business groups or publicly listed on a stock exchange, i.e., they are less likely to acquire targets in different sectors than their own. Finally, we find that the effects of acquirer's ownership identity are linked to the host country selection and diversification choice.

This paper makes several significant contributions. Firstly, we contribute to the literature on cross-border industry diversification by introducing the international dimension. The foreign acquisition is often seen as a risky way to put a corporate strategy into action (Datta, Pinches \& Narayanan, 1992; Cartwright \& Schoenberg, 2006). The implications of entering a foreign country while diversifying into a new industry at the same time will be difficult for most firms. By combining these two different streams of literature on diversification, our results add an international dimension to the industry diversification 
literature (Hautz, Mayer \& Stadler, 2013). Secondly, we examine the role of ownership identities on diversification strategies. Different types of firms will tend to follow different rationale and motivations, and make disparate decisions regarding industrial diversification while entering foreign markets through acquisitions. In spite of the vital role of ownership in firm strategies in emerging markets, prior studies typically consider each of these ownership types individually in their studies (Cui \& Jiang, 2012; Nicholson \& Salaber, 2013; Liu, Li \& Xue, 2011), whereas, our work provides a comprehensive view of various types of ownership and Chinese firms diversification strategy.

By building on a theoretical framework of economic and strategic arguments, we shed more light on the behavior of Chinese acquirers, which are important antecedents not captured in current studies. Thirdly, we also explore contextual factors such as the location of host countries, especially, the Chinese acquisitions of developed country targets. The impact of culture on Chinese cross-border acquisitions, especially in the acquisition of targets in developed economies like the US, has been studied by several authors (Nicholson \& Salaber, 2013; Dietz, Orr \& Xing, 2008). In this paper, we further extend the argument on ownership identity in CMNEs' diversification in foreign markets. Our work provides evidence that acquirer ownership identity is intricately linked to the target host country and will direct the acquirer's diversification choice.

The reminder of the paper is organized as follows. The next section provides a theoretical framework and presents our hypotheses. In section 3, we document the methodology and data collection process. Section 4 provides a summary of results and findings. Section 5 concludes with a discussion.

\section{Theoretical framework and hypotheses}

\section{Chinese business context}

Before we delve into different types of ownership identities, it is important to note that ownership characteristics are hugely influenced by the institutional environment of the home country (Khanna \& Palepu, 2000), and different types of firms might have different rationales for diversification strategies. Due to the heterogeneity of the home country context, we focus on China for the rest of the paper. The Chinese foreign direct investment has grown considerably over the last couple of decades (Berrill, 2015). Previous studies have looked at the underlying reasons for rapid internationalization by the Chinese firms (Child \& Rodrigues, 2005). One of the drivers for internationalization, according to Rui, and Yip (2008), is the intense competition between local companies and their global rivals. It has been suggested that 
Chinese companies internationalize to address competitive disadvantages (Child \& Rodrigues, 2005). In some cases, these Chinese acquiring companies involved in manufacturing industry leverage competitive advantages derived from their low-cost domestic manufacturing to enter foreign markets (Rui \& Yip, 2008). In other cases, the underlying motives for foreign investment by Chinese firms range from knowledge-seeking to resource-seeking, and these companies engage both in developed as well as developing economies for strategic reasons (Nicholson \& Salaber, 2013). These rationales to internationalize would influence firms' decision to engage in industrial diversification in foreign markets.

\section{The role of ownership in determining the decision to diversify into different industries in foreign markets}

The role of ownership structure and ownership identity play important functions in the decision to diversify. Ownership structure has been considered as a potential explanation for diversification (Hautz et al., 2013; Lane, Cannella Jr \& Lubatkin, 1998). Also, ownership identity (i.e., type of owner) is considered as an essential mechanism to influence firm strategies, such as the decision whether to diversify outside the core industry. Ownership identity plays great role in the oversight and incentives management and influences corporate goals (Milhaupt \& Zheng, 2014) and strategic choices (Ramaswamy, Li \& Veliyath, 2002). For example, (Tihanyi, Johnson, Hoskisson \& Hitt, 2003) examine the relationship between institutional ownership, the board of directors and industrial diversification of firms in foreign markets within an agency framework. They argue that in the case of US firms, different types of institutional owners have different stakes in firms' strategies, and contextual factors such as boards and technological opportunity accentuate these differences. Their results indicate that pension funds' long-term orientation facilitate internationalization in industries with high technological opportunities. Therefore, we need to differentiate across different types of ownership. However, few studies have systematically examined crucial different ownership types in China. From the literature, we have identified three key ownership identities that might influence CMNEs. In this section, we will look at different types of ownership identities and explore their effects on foreign industry diversification, in the context of CMNEs.

\section{Government ownership}

Governments have long been acknowledged as critical sources of dependency for firms (Lester, Hillman, Zardkoohi \& Cannella, 2008). The government can influence firms in several ways, such as directly taking ownership in SOEs, providing subsidies directly or using regulation and 
policies. Compared to other forms of influence, direct government ownership or state ownership allows the extensive government control of operations. In the Chinese context, government ownership in national firms constitutes an integral part of the national economy. Despite their low numbers compared to a total number of businesses in China, governmentowned firms command high levels of assets as compared to total assets of all firms. According to a study by Huang, and Renyong (2014), in 2011 in China, only 5.2\% of the total firms were state-owned firms, yet they controlled $41.68 \%$ of the total asset. Despite rapid liberalization of the Chinese economy, many Chinese companies holding significant industrial and financial assets are still majority controlled by the central and local government (Huang \& Renyong, 2014). In domestic acquisitions, authors have found that Chinese firms that are owned by the government are less likely to diversify across industries (Lin \& Su, 2008). The benefits of industrial diversification were observed to be less in the case of government ownership of diversifying firms due to political costs of tunneling and expropriation. Recent studies also found that regarding valuation the diversified SOEs are valued less, thus, providing further evidence of political cost hypothesis of diversification ( $\mathrm{Lin} \& \mathrm{Su}, 2008$ ).

Beyond the domestic context, the government ownership might also explain the targets that these Chinese companies pursue in their foreign acquisitions. State ownership might dictate the internationalization patterns and motives for cross-border acquisitions (Rui \& Yip, 2008). Government ownership could influence the behavior of these companies by filling in the institutional voids and facilitate internationalization activities such as foreign acquisitions by providing resources and capital (Inoue, Lazzarini \& Musacchio, 2013; Ralston, TerpstraTong, Terpstra, Wang \& Egri, 2006). Thus, in this study, we go beyond the internationalization motives of CMNEs and query the influence of government ownership on a strategy of industrial diversification in foreign countries.

Following the previous framework, we argue that regarding internationalization strategy, the government ownership might provide several reasonings for why the firms are less likely to undertake industrial diversification in foreign markets. Firstly, state companies usually follow national interests, not commercial logic. Some acquisitions by SOEs need to meet the national duties rather than further the strategic objectives of the firm. For example, Rui, and Yip (2008) propose that SOEs belonging to resource-intensive sectors typically acquire targets rich is natural resources to fulfill their obligations towards national tasks with the cost of acquiring the least of considerations. This is critical in sectors like oil and gas, where the foreign acquisitions were means of getting access to fuel resources and securing future access to natural resources. These transactions are not just restricted to just natural resources 
but have also been seen in other industries. For example, the growth and expansion of stateowned and controlled Chinese telecommunications companies can partly be attributed to their ties with the Chinese state. Companies such as ZTE are more likely to invest in related deals in Africa to build up local infrastructure (Li \& Cheong, 2017). Hence, Chinese SOEs would seek foreign acquisitions in the same industrial sector to follow state directions.

Secondly, the policies like "go global" will also have an impact on the globalization strategy by the Chinese government-owned firms (Luo \& Tung, 2007; Cai, 1999; Deng, 2007; Chen \& Findlay, 2003; Luo, Xue \& Han, 2010; Singh, 2009; Sun, Peng, Ren \& Yan, 2012). This is particularly true in the case of national champions which might be the first companies going abroad to fulfill the government's globalization mandate (Wang, Hong, Kafouros \& Boateng, 2012). Sun et al. (2012) confirm that Chinese SOEs play the leading role in crossborder acquisitions. In these cases, the government ownership may provide opportunities and access to cheap finance which can increase the likelihood of foreign expansion, and at the same time, impel these firms to follow the government's strategy. It is likely that in these circumstances, state firms are likely to acquire in the same industrial sector.

Thirdly, in China, managers in SOEs are considered government officials. They tend to follow long-term orientation and have more conservative strategies compared to professional managers (Qian, 1996). One failure in a significant investment is likely to cost them their entire political career. So, managers in government-owned firms are less likely to follow high-riskhigh-reward investments. Also, SOEs might have additional performance expectations like generating employment, providing public goods and national security (Tan, 2001), all of which goals yield to a preference for less risky-taking behavior in international endeavors. The Chinese central bank governor has stated that "Some investments do not meet our industrial policy requirements for outward investment ... they are not of great benefit to China and have led to complaints abroad. Therefore, we think a certain degree of policy guidance is necessary and effective" (Feng, 2017). Thus, managers in these firms will be encouraged to engage in value generating strategies, and probably, focus on their core industry to improve the national security mandate. As a business analyst states, "It's clear Chinese regulators decided that ... they want to reassert the government gatekeeper role in to the outbound flow of investments" (Feng, 2017). Child, and Rodrigues (2005) have discussed the government restrictions on Chinese firm's decision making. Nolan (2002) discusses the ambitions of the Chinese government to manage the internationalization process of its companies. As a consequence, if these managers perceive that diversification is likely to create political dissatisfaction they are unlikely to engage in unrelated diversification in their cross-border activities. 
Therefore, the government ownership will reduce the chance of cross-industry acquisitions abroad, and we argue,

Hypothesis 1. Government ownership of CMNEs will decrease the likelihood of their industrial diversification in cross-border acquisitions.

\section{Business group membership}

A business group is a set of legally independent firms 'bound together by a constellation of formal and informal ties' (Khanna \& Rivkin, 2001) and coordinated by a central or core entity (Leff, 1978). According to the State Council of China, one of the primary objectives of forming business groups in China is to restructure large enterprises into cross-industry, cross-region business groups and transform them into national champions that can compete in both the domestic and global markets (Nolan, 2001; Yiu, 2011). The importance of business groups and business group membership in the emerging economies has been highlighted in various studies (Khanna \& Palepu, 2000; Khanna \& Rivkin, 2001; Lu \& Yao, 2006; Kim, Hoskisson, Tihanyi \& Hong, 2004; Maman, 2002; Gaur, Kumar \& Singh, 2014). The ubiquitous presence of business groups is mostly an organizational response to strategic factor market and investor protection imperfections in developing economies (Khanna \& Rivkin, 2001; Leff, 1978; Almeida \& Wolfenzon, 2006). In the absence of institutional intermediaries, business groups fill in the voids by generating their internal markets for financial capital and managerial talent (Ma, Yao \& Xi, 2006).

It has been observed that companies that are part of the business group in emerging economies are more likely to diversify across industries in their home country which authors have argued is due to their favorable position in the local political eco-system (Khanna \& Yafeh, 2007). However, these observations have been made mostly for domestic acquisitions (Khanna \& Palepu, 2000; Khanna \& Rivkin, 2001; Lu \& Yao, 2006), and have been linked to explanations like the market imperfections, survivability prowess, weak contract enforceability. Khanna, and Palepu (2000) argued that in India, business groups create an internal market and affiliation of the most diversified business groups outperformed unaffiliated firms. This applies equally to a country like China where the cost of capital is high for individual private or family-owned firm (Erdener \& Shapiro, 2005; Huang \& Renyong, 2014; Ramasamy, Yeung \& Laforet, 2010).

Authors have suggested that business group membership is likely to increase the chance of internationalization of a firm from emerging country (Gaur et al., 2014). Singh, and Gaur (2013) and Kumar, Gaur, and Pattnaik (2012) observe a positive effect of group affiliation on 
foreign investments. Kumar et al. (2012) have examined the role of inherent trade-off between strategies of product and geographical diversification for Indian business groups. They suggest that, on average, business groups are less likely to pursue a strategy of product and geographical diversification as these domestically diversified firms are less likely to consider geographical diversification as one of their risk-reduction strategies. In the context of China, prior studies have documented that business group affiliations would fill ownership voids in China's transition economy (Ma et al., 2006). Similar to government-owned CMNEs, Chinese business groups also faced a great deal of scrutiny of their strategies and internationalization activities from the Chinese government (Hahn \& Lee, 2006). These business groups were expected not to expand or diversity extensively (Lee \& Woo, 2001). Given these political pressures and the advantages of ownership control to business group's core entity under weak investment protection regimes and the many risks of industrial diversification in foreign countries, business group's core entity would rather avoid high costs of industrial diversification abroad. Based on these arguments, we propose that,

Hypothesis 2. Business group membership of CMNEs will decrease the likelihood of their industrial diversification in cross-border acquisitions.

\section{Publicly-listed firms}

A few studies have looked at the differences between public listed firms (PLFs) and private acquirer firms regarding their internationalization strategy. It is not yet well documented whether the public status of emerging market acquirers will make a difference on a strategic decision such as industry diversification in the global context. In the context of CMNEs, we argue that PLFs and private firms have different characteristics and strategic decision-making process.

To begin with, Initial Public Offering (IPO) process of Chinese companies will serve as an information-processing and asset valuation mechanism (Chen, 2004; Liu \& Lu, 2007). IPO listing in Chinese stock exchange (Shanghai Stock Exchange or Shenzhen Stock Exchange) is a very complicated process and requires fulfillment of various vital criteria ${ }^{1}$ (Chen, 2004). Unlike stock exchanges in advanced countries which use a registration system, IPO in China cannot be launched on the mainland without passing an official assessment by regulator China Securities Regulatory Commission (CSRC) (Pistor \& Xu, 2005). This is an

\footnotetext{
${ }^{1}$ http://english.sse.com.cn/listing/stocks/requirements/ http://www.sse.com.cn/marketservices/listing/tobelisted/listcondition/\#1
} 
extended evaluation system, and hundreds of companies need to queue up for months to get approved (Chen, 2004). So PLFs in China usually have better performance and necessity to sustain their profits compared to unlisted firms (Liu \& Lu, 2007). Also, foreign investments might require access to capital and opportunities of Chinese firms to long-term debt is highly selective as it is provided by Chinese state bank (Xu, Xu \& Yuan, 2013) and is strictly controlled by the state (Chen, 2004; Bai, Lu \& Tao, 2006).

Secondly, PLFs have stricter corporate governance mechanisms, a higher level of transparency and are subject to constant monitoring by both regulators and shareholders. On the one hand, the CSRC monitors all PLFs in great detail ${ }^{2}$. On the other, due to a higher level of transparency and liquidity, market feedback for public-listed acquirers is much better. Individual shareholders and institutional investors on the market will also provide additional monitoring on firm behavior by buying and selling shares (Liu \& Lu, 2007). Thirdly, similar to the distinction in other countries, the process of strategic decision making is different for PLFs and private unlisted acquirers (Xu et al., 2013). The idea of a corporate board is not common in private companies (Chen, 2004), whereas public-listed companies usually require external board members to decide on essential internationalization decisions, making firms more likely to focus on significant synergy within the same industry and reduce agency costs and preference for unrelated deals. Lastly, whereas in advanced countries, there is an active managerial market, due to traditional Chinese culture and relationship-based management (Cai, 2002), managers that misbehave in Chinese companies are less likely to find a new job. Creation of Central Commission for Discipline Inspection (CCDI) in China adds to this atmosphere where corruption is viewed as a negative social and normative idea (Hornby, 2017). This behavioral aspect points to the convergence of interests between managers and shareholders.

Taken together, we argue that compared to private firms, PLFs are less likely to diversify in international markets due to a higher level of firm monitoring by shareholders and additional monitoring by regulators.

Hypothesis 3. Publicly-listed status of the CMNEs will decrease the likelihood of their industrial diversification in cross-border acquisitions.

\footnotetext{
${ }^{2}$ www.csrc.gov.cn
} 


\section{Host country development}

The location choice of Chinese firms internationalizing also varies according to their ownership (Ramasamy et al., 2010). We are interested in examining whether different types of acquiring firms behave differently in developed and developing host countries and whether host country development will affect the decisions to diversify across CMNE's core industry.

Recent studies have suggested that cross-border acquisitions by emerging market acquirers differ significantly in developed and developing countries. For example, Nicholson, and Salaber (2013) find that both Chinese and Indian acquirers gain abnormal returns when the target firm is located in a developed country. This follows our earlier strategic argument that acquisitions in developed countries usually reflect the acquisition of complementary capabilities and strategic assets that are not available in the home country. Recent empirical studies such as Gubbi, Aulakh, Ray, Sarkar, and Chittoor (2010) and Sun et al. (2012) support our conjecture that the acquirer's emerging market home context will differ.

The context is relevant in cases where the firms were internationalizing to escape their limited domestic market for advanced corporate governance or technological base. Authors have called this the "strategic exit" of Chinese companies (Boisot \& Meyer, 2008). Acquiring a related target in advanced countries will enable the acquiring firms to tap into the technology and brand-name in the same industry. This can potentially create more economies of scale, and Chinese companies can benefit from synergies between different business units, especially this could help the transfer of critical capabilities like the managerial skills between foreign target firms and the Chinese companies. At the same time, given the stable institutional environment in the developed countries and the much more extensive market for corporate control, Chinese firms might easily adopt a risky stance of industrial diversification with the knowledge that there are likely to be future exit options for their investment if they do not derive synergies from their investments.

Chinese SOEs are more liable to target risky political environments and seek access to natural resources (De Beule \& Duanmu, 2012), whereas, the private firms are market-seekers and engage in less risky countries (Alden \& Davies, 2006). On the other hand, SOEs will target advanced country targets to develop "national pride" by paying a higher premium. Regarding diversification strategy in foreign location by the business group affiliated firms, the underlying motivations for diversification like market imperfection and access to internal markets might not be relevant. This is particularly the case if the emerging market companies like those from China target developed economies like the US where the institutional frameworks are better developed to engage with contractual issues between the firms. 
In contrast to firms in the advanced economies that enjoy relatively easy access to information, this is a particular issue for emerging market firms which face differential access to information on target companies, owing to institutional weaknesses and constraints in those markets. Similarly, there is limited information on the private CMNEs in the public domain which can be a significant issue in the developed markets. Much of the negative outlook on emerging market acquirers is linked to their opacity and lack of information in the global markets. Thus, publicly listed firms from China might experience openness and transactional flexibility while engaging in cross-border acquisitions and they can leverage this by targeting only firms in their sector but also across industry boundaries. This is very beneficial for Chinese firms in developed markets as they can acquire managerial skills not only relevant for their industry but via vertical integration can benefit from skills in other industries. Also, vertical integration and acquisitions across industries will help these firms protect their domestic markets via the acquisition of resources and competencies to manage global competition.

Thus, we argue that host country will matter for these Chinese acquirers, and could impel them to engage in industrial diversification.

Hypothesis 4a. The relationship between government ownership and decision to diversify across a firm's core industry is moderated by host country level of development with developed markets having a positive impact on diversification by government-owned firms.

Hypothesis 4b. The relationship between business group affiliation and decision to diversify across a firm's core industry is moderated by host country level of development with developed markets having a positive impact on diversification by business group affiliated firms.

Hypothesis 4c. The relationship between publicly-listed firms and decision to diversify across a firm's core industry is moderated by host country level of development with developed markets having a positive impact on diversification by publicly-listed firms. The theoretical framework is briefly articulated in Figure 1. 


\section{Data and methodology}

\section{Data collection}

The initial data set on cross-border acquisitions come from SDC Platinum, which is produced by Thomson Reuters Financial Securities Data. This database provides access to global financial market data and is widely used in studies on mergers and acquisitions and is extensively used by previous studies (Liou, Chao \& Yang, 2016). We collected information on all completed Chinese cross-border deals and obtained 2000+ deals where Chinese bidders acquired some stakes in their targets during 1986 and 2014 (Buckley, Yu, Liu, Munjal \& Tao, 2016b). Next, we cleaned the data for deals where the bidder owned a majority stake in the target company after the transaction (50\% and over). Using this criterion helps us identify deals which involved considerable managerial and financial investment by the Chinese firms and we could confine our sample to non-portfolio deals. This considerably reduced our sample and we have 153 deals which belong to 16 host countries. This implies that most of the acquisitions ( $94 \%$ ) by the Chinese firms are focused on portfolio development. The sample is limited by the availability of variables on the main deal and firm characteristics, and the sample at this stage is 125 deals which include both acquisitions in developed and developing countries. Table 1 illustrates the distribution of the country. Hong Kong has the most number of deals (51 in total), followed by advanced nations such as United States (16 deals), Australia and Canada with 17 deals each.

\section{Insert Tables 1 about here}

\section{Dependent variable}

We use the SDC Platinum database to identify if the acquirer and targets belonged to the same industry. The dummy variable, Diversification, takes value one if the target does not belong to the same industry as the bidder, and 0 otherwise. A firm's core business is commonly defined as the business segment that generates the most significant revenue for the firm (Rumelt, 1974). Following existing literature, we define a firm's core business industry as the four-digit US Primary Standard Industry Classification (SIC) industry. Acquisitions are classified as diversified if the acquiring firm is not in the same business segment as the target identified by four-digit SIC codes (Moeller \& Schlingemann, 2005; Denis, Denis \& Yost, 2002; Shleifer \& Vishny, 2003). By checking for match of all four digits would imply testing for horizontal mergers between firms within the same primary economic activities (Barai \& 
Mohanty, 2014) or whether the deals are diversified deals. Thus, deals which are not matched at the 4-digit level are deemed as unrelated diversification.

We do acknowledge the limitations of this measure, including the lack of information on the percentage of sales from the diversified business. As Barai, and Mohanty (2014) have suggested, in emerging countries, the stricter definition of relatedness and diversification are more laborious to generate due to lack of data at the firm-level reporting. We also did our best to find alternative measures of diversification as detailed in the literature (Ramaswamy et al., 2002; Sun, Peng \& Tan, 2017; Nocker, Bowen, Stadler \& Matzler, 2016; Li, He, Lan \& Yiu, 2012; Neffke, Henning \& Boschma, 2011; Haleblian \& Finkelstein, 1999), but we did not find consistent data for all the acquirers and targets in our sample.

\section{Independent variables and moderator}

We create three dummy variables to indicate the identity and type of majority owners. We created three mutually exclusive categories of ownership to avoid confounding our results between different kinds of ownership. We use a dummy variable, Acquirer government, to indicate whether the acquirer is government-owned enterprise or government is the majority stakeholder in this firm. We obtained this information from various sources like SDC Platinum, company website, annual filings and newspaper articles. This variable takes value one if there is evidence of government ownership or zero in other cases. The dummy variable, Acquirer business group, is used to indicate if the Chinese company is part of a business group. We used firm-level information from SDC Platinum database to classify our acquirers. This business group affiliated firm can be either government-owned business group or private business group. This variable takes the value one if true, 0 otherwise. Acquirer publicly listed is a dummy variable, and takes the value of 1 if the acquirer is a public-listed company or zero otherwise. All these variables are collected from the ownership data from Thomson one. We removed observations where firms evidenced multiple types of ownership. Following this cleaning, we had 90 observations in our sample. Also, as a proxy for the level of economic development in the host country, we have created a dummy variable (Target national development) which takes value one if the target country belongs to one of the developed countries as classified by the World Bank.

\section{Control variables}

We also include various controls for variation in the data arising from numerous sources: the deal-level, firm-level, sector-level and country-level differences. Firstly, we have included two 
deal characteristics. The method of payment (cash or equity) may affect risk positions in the target. Regarding higher volatility and valuation problems, acquiring firms may use equity ownership instead of paying cash. Prior studies also document that cash payments are more likely in the same industry due to the familiarity of the industry environment. So, we control for a method of payment by including a dummy variable of cash (Linn \& Switzer, 2001). Cash is a dummy variable equal to one if the acquisition is cash-financed, and zero otherwise.

Percent acquired is the acquired stake in the target firms (Nicholson \& Salaber, 2013; Moeller \& Schlingemann, 2005). We expect that acquirers may take a higher percentage of stake in the same industry. Book/price Ratio is the book to market ratio of the target (Moeller \& Schlingemann, 2005; Lang, Stulz \& Walkling, 1991). A higher value is more likely to indicate that target is more valuable. This is relevant when considering diversification since companies need to consider the quality of potential targets.

We also looked at whether the deal is a market-seeking move by the acquirer. Market Seek is included as a dummy variable and takes the value of one if host country GDP is higher than the home country in the year before the acquisition (Liou, Rao-Nicholson \& Sarpong, forthcoming). GDP is usually used to measure the size of the host market. We would expect that in market-seeking deals, the acquirers will tend to prefer targets in the same industry, usually with distribution channels in this industry. To control for industry heterogeneity, we generate industry groups based on one-digit Primary US SIC codes. We clustered the deals by sectors to control for within industry heterogeneity.

Further, we have included variables to control for cross-country differences. The general business environment such as legal, political, economic and social factors would influence firms' decisions to diversify (Nicholson \& Salaber, 2013; Ghemawat, 2001; Berry, Guillén \& Zhou, 2010), so we control for several cross-country differences between China and the host countries. Historical links are included as a dummy variable and take value one if true, zero otherwise. In this case, historical links imply whether host country has a large number of Chinese diaspora or ethnic Chinese. Studies have shown that presence of ethnic ties can generate synergies in the international business (Jean, Tan \& Sinkovics, 2011; Zaheer, Lamin $\&$ Subramani, 2009). For example, in Singapore, Chinese are the dominant ethnic group. Similarly, Jean et al. (2011) argue that despite decades since the relocation of Chinese in foreign countries, many of them still maintain close ties with their ancestral home. In the host country with historical links, the acquirer is more familiar with the host country environment. This variable also takes into account the possibility of round-tripping in Hong Kong. Legal distance is the difference of legal distance between the home (China) and host countries. 
Economic distance indicates the difference of level of economic freedom between the home (China) and host countries. Both factors will potentially influence decision-making in foreign markets. Buckley, Forsans, and Munjal (2012) find that foreign investment varies with foreign exchange rate variation. The data on foreign exchange was obtained from Oanda website, and variable Foreign exchange is calculated as a ratio of acquirer and target currencies.

\section{Model specification and analysis}

To examine the relationships between the ownership identities and diversification we use probit regression analysis since the dependent variable is a binomial variable (Diversification). These regressions can be estimated by the maximum likelihood method. The model can be summarized as:

$Y_{n}=b_{o}+b_{i} X_{i}+b_{j} I_{j}+b_{k} C_{k}+E$

where: $Y_{n}$ is the dependent variable, $X_{i}$ stands for independent variables, $I_{j}$ are the moderating variables, and $\mathrm{C}_{\mathrm{k}}$ denotes control variables. The coefficients in Probit models cannot be interpreted directly, so we will use marginal effects and plot the interaction terms.

\section{Descriptive statistics}

Table 2 includes information on the source and description of data for all variables. Table 3 presents the descriptive statistics and distribution of the sample. In Table 3, 62 or (67\%) of the 92 deals involve industry diversification. The mean difference test shows that there is a significant difference between the diversification strategy adopted by the business group firms and publicly listed companies and these businesses are more likely to invest in their industry during internationalization.

\section{Insert Tables 2 and 3 about here}

Table 4 reports the correlation coefficients across all our variables. To analyze potential issues of multicollinearity, we analyze Variance Inflation Factors (VIF). The mean VIF reported is 2.44 and all scores are less than 4.44 (highest for the variable Target national development), far below the standard cut off point of 10 for multicollinearity (Hair, Anderson, Tatham \& William, 1998).

Insert Table 4 about here 


\section{Results}

Table 5 presents estimates of Probit regressions. The Column (1) provides estimates of our baseline model which contains all our control variables. For the control variables, we find that the price to book ratio of the target (Book/Price Ratio) will have a positive effect on the diversification strategy of the Chinese companies, indicating that firms tend to acquire undervalued foreign assets, regardless of the industry. Historical links between the acquirer and target countries will negatively affect the decision to diversify implying that Chinese companies prefer to consolidate their industrial capabilities in these countries and choosing to diversify in historically unrelated countries.

Insert Table 5 about here

In Model 2 to Model 4 of Table 5, we have included direct effects of ownership on the likelihood of diversification into a different industry. The coefficient estimates from the main model demonstrate Chinese firms' propensity to diversify in international acquisitions. The Pseudo R2 for our models lies between 0.186 and 0.242 . The log likelihood ratios can be used in comparisons of nested models. Model 2 presents the results of H1. In Model 2, the p-value indicates that our model is statistically significant. The signs of Probit models are meaningful. We find out that government-owned is negatively linked to the propensity to diversify ( $\beta=$ 1.000 , significance at $1 \%$ level). Our findings lend support for Hypothesis 1 that governmentowned firms are less likely to diversify.

Model 3 includes the results of business group membership. Business group membership is negatively correlated with the tendency to diversify $(\beta=-0.992$, significance at $1 \%$ level), thus supporting our Hypothesis 2 . The results in Model 4 indicate that the probability of unrelated acquisition into a different industry is negatively linked to publicly-listed acquirers ( $\beta=-1.459$, significance at $1 \%$ level). So, we also supported our Hypothesis 3 on publicly-listed firms.

The moderating effects of host country development status are tested in Model 5-8. The Pseudo R2s are between 0.210 and 0.431 (full model). The results of the empirical findings indicate that all types of ownership identity we captured here behave differently in developed and developing host countries. The host country interactions with government ownership ( $\beta=$ 1.417 , significance at $5 \%$ level), business group ownership $(\beta=1.316$, significance at $10 \%$ level), and publicly listed firms $(\beta=1.665$, significance at $5 \%$ level $)$ are all positive, and 
significant in case of direct effect variables. Thus, though publicly listed is not significant in the full model, rest of the ownership types are positively and significantly related to the host national development in explaining the international diversification strategy of the Chinese firms.

To interpret the results of the interaction terms, we plot the interaction terms. In Figure 2, we plotted the interaction terms for the host country and main ownership identities. Government-owned firms, a business group affiliated businesses and publicly listed firms are less likely to diversify in emerging markets.

\section{Additional analyses}

As a robustness check, this procedure has the advantage of studying acquirers that enter similar industries within the broad categorization. We include industry controls at two-digit SIC. We also conducted by splitting our samples between service and manufacturing firms and our results are robust to these sectoral differentiations. We also conducted another set of analysis by considering only those deals which were carried out after 2000 . Our results for this subsample are similar to those reported in this paper.

Next, as shown in Tables $6 \&$, we consider diversification at different levels of match of SIC-codes. We identify diversification at 1-digit, 2-digit and 3-digit levels. We observe from Tables 6 and 7 that most of our results are supported by this analysis. We find that at 1-digit diversification all interaction effects are significant.

Insert Table 6 and 7 about here

Since our main dependent variable is a binary variable, we also conducted additional analyses by constructing continuous variable to measure the level of industry diversification. Following prior studies, we generated a variable of diversification based on 4-digit primary SIC codes of the industry of the acquiring and target firms. Following similar studies such as Barai, and Mohanty (2014) and Haleblian, and Finkelstein (1999), we measured the level of diversification between the acquiring and target firms. Table 8a provides the details for generating the continuous variable for the level of diversification. Table $8 \mathrm{~b}$ provides some descriptive statistics for this continuous variable

Insert Table $8 \mathrm{a}$ and $8 \mathrm{~b}$ about here 
The correlation between our dummy variable of diversification and the measurement of the level of diversification is 0.9239 , indicating that our measurement is robust. We have also run all our models using this alternative measurement of the level of diversification, and the results are similar to those presented in the main model. The results for this robustness check have been included in Table 9. As the dependent variable is no longer a dummy variable and is truncated at the upper level value of four, we use tobit model in our analysis.

Insert Table 9 about here

We also used other measures for some of our controls. For example, we used GDP of the host country as an alternative measure of market seeking. Results of these analysis are similar to those presented in this paper. For historical links, we also looked at the strength of local activism of Chinese diaspora in the host countries to measure the current effect of the historical link. We created a dummy variable to indicate whether Chinese diaspora was engaged in organizing visits for trade delegations and hosting Chinese cultural events and these variables took value one if true and zero otherwise. Then, these individual values were combined to obtain the value for historical links. The analysis presented results which are similar to those presented in this paper.

\section{Discussion and conclusions}

In this paper, we examined the impacts of ownership identity and host country location as the possible determinants of the diversifying acquisitions undertaken by the Chinese firms. Though there are several studies that investigate the internationalization of the Chinese companies and their possible motives (Nicholson \& Salaber, 2013; Rui \& Yip, 2008; Luo \& Tung, 2007; Child \& Rodrigues, 2005; Cai, 1999; Deng, 2007; Chen \& Findlay, 2003; Luo et al., 2010; Singh, 2009; Sun et al., 2012; Deng, 2009), the impacts of heterogeneity in ownership identity among Chinese firms in foreign markets is rarely studied in the literature. Therefore, we combine the ownership literature with international business strategy literature to explain how ownership identities of Chinese companies have affected firms' strategic decisions to diversify or not in foreign acquisitions. We argue that government ownership, membership of a business group and public-listed status will have negative impacts on the likelihood to diversify by the internationalizing Chinese companies. As suggested by the extant literature these companies face high pressure due to government interference, in the case of government-owned firms, and intervention by other business group member or hierarchical parent, in the case of business 
group firms (Huang \& Renyong, 2014; Deng, 2007). These competing objectives of the parent organization and government policies might drive the internationalization by the Chinese companies, and their choice of the target will be moderated by their ownership structure.

According to institutional theorists, the legitimacy threats residing in the large national differences in the level of economic developments will determine resources available in the targets (Gubbi et al., 2010). Hence, emerging market companies would typically be expected to acquire in the same industry when entering advanced countries to explore new resources. One explanation for this observation could be the growing need for Chinese firms to improve and build their managerial capabilities and human capital within the firm's boundaries. Acquiring target companies from a different background could help improve the organizational structure and corporate governance and combined with cross-industry characteristics this could imply that Chinese firms can move up or down the value chain and acquire capabilities in the upstream or downstream markets.

Another argument for this observation could be that firms are motivated by government's go global policy and access to cheap capital and are not strategic in their perspective on foreign acquisitions are willing to acquire targets in other sectors which in the long term could lead to integration problems, and in reality, have very little strategic value. ChemChina's acquisition of Syngenta has been noted to be driven by "part of Beijing's desire to improve food security, reduce reliance on foreign seed makers and develop an agribusiness industry" (Toplensky, 2017). We find that Chinese firms engage in consolidation activity and acquire companies that belong to their industry. One argument, similar to those presented in (Rui \& Yip, 2008), could be that these firms acquire their competitors to pre-empt the likely competition in the Chinese domestic markets.

\section{Theoretical contributions}

We contribute to the theoretical discourse on cross-border industry diversification by presenting the international dimension. This work adds to the literature on international dimension to the industry diversification (Hautz et al., 2013), especially in the context of CMNEs. Next, we provide evidence on the role of ownership identity in the diversification strategy. Most of the prior works have considered these identities in partial terms and have explored one or combination of these types of ownership without examining them all in the same study (Cui \& Jiang, 2012; Nicholson \& Salaber, 2013; Liu et al., 2011), whereas, we consider these together in this paper. Furthermore, we also add host country location as an important dimension to this argument on international diversification of CMNEs. The impact 
of culture on CMNEs has been studied by several authors (Nicholson \& Salaber, 2013; Dietz et al., 2008) and we explore this from the perspective of both developing and developed markets. This paper provides evidence that acquirer ownership identity is closely associated with the host country and will direct the acquirer's diversification options.

\section{Generalizability}

The specific context of our paper is China, where government ownership, business group and publicly listing are common. The sample and results reported here are typical of CMNEs. Our results indicate that different ownership identities in China have implications on industrial diversification in foreign markets. Some of the arguments (business group affiliation and public-listing status) are not context-specific and will apply to firms from other developing countries in the Asia Pacific Region. Thus, some of the results the study may be generalizable to other emerging economies with caution as these firms may share some characteristics with Chinese firms due to the prevalent institutional voids. For example, like China, business group play an important role in India (Gaur \& Delios, 2015). Similarly, private companies going for public listing is a sign that a company had reached a certain threshold of size and profitability to attract public investors for additional funding. The stock exchange and investors would provide a monitoring role in other Asian countries is similar to China.

It is important to note that the results of Chinese SOEs may be different from SOEs from other democratic countries. Ramaswamy et al. (2002) argue that in the context of India, government agencies will not be related to diversification strategy. Although some of the riskaverse arguments apply to the SOE literature in general (Boubakri, Cosset \& Saffar, 2013), Chinese SOEs have certain characteristics that differ from Western SOEs and SOEs in other emerging countries. Peng (2005) summarizes and underscores the challenges of conducting research in China, especially in the context of state ownership and understanding its importance on firm performance in Chinese business context. We must be careful when generalizing the results to other emerging countries. As pointed out earlier, the effects of ownership on diversification is contextual upon the level of formal regulation and monitoring and informal information channels.

\section{Limitations and future research}

This paper is not without its limitations. Firstly, we focus only on the majority stake acquisition of Chinese firms. Minority stake ownership and potential use of real options perspective may 
involve different points of view on risk-averse and the relationship between owners and foreign market decisions (Xu, Zhou \& Phan, 2010). Though beyond the scope of this paper, future research could look at the whole set of Chinese cross-border acquisitions and maybe other types of investment, such as greenfield projects. We believe that our sample, which consists of culturally and geographically diverse host countries, does not bias the results presented in this paper, but having a sample of Chinese acquisitions that include both majority and a minority shareholding in all countries might provide a fine-grained view of the diversification strategy.

Secondly, we present limited information on the temporal differences that could emerge in the overseas acquisition strategy by the Chinese companies. Hence, future studies could focus on the changes that occur in the diversification strategy of the same firms over a period. Furthermore, we do not examine the performance implications of these diversifying acquisitions; hence, one of the future avenues for research would be to investigate the shortterm and long-term performance of diversification of Chinese firms in foreign markets.

Another key limitation is the lack of data on non-core businesses for all the acquirer and targets. We had data on this for less than $10 \%$ of our sample and all the other acquirer and target firms listed only one primary SIC code. This is precisely the idiosyncratic nature of this data set. In future studies, authors can identify this information by either carrying out a survey of the managers of the firms involved in foreign acquisitions or creating a much smaller sample of deals which includes the data on firm-level non-core businesses. Similarly, many of the suggested diversification indices used in the prior literature are hard to create for geographical and industrial diversification due to the nature of our data. Also, though the diversification measured used in this study provided us with a granular view of diversification, it is not without its limitations. Currently, we consider all firms belonging to the different industry as equals. We know in reality this is far from accurate, some industries might be more related than some others. Nevertheless, we argue that our paper provides a more nuanced view of how firms in different industries might consider ownership levels in their targets in foreign markets.

Similarly, various studies suggest the importance of evaluating the social integration process in the cross-border acquisitions (Liu \& Woywode, 2013), future studies could look at the challenges in the same host countries by Chinese firms acquiring in different sectors. These nuanced studies will help distinguish the underlying reasons for diversification between emerging and advanced host markets as well as differences observed between industrial sectors. 


\section{Managerial relevance}

The findings of the current study demonstrate a systematic way of understanding the diversification strategy adopted by Chinese multinational firms. For this research, we look at single country acquirers who have acquired majority shares in targets around the world. We find support for our hypotheses that the ownership types provide a reasonable and robust explanation of the diversification strategy adopted by the Chinese firms.

We also observe that in developed host markets Chinese firms are more willing to engage in diversification strategy. This might indicate that CMNEs adopt a strategy of vertical integration or diversifying into industries which might benefit from their existing competencies and skills. This will help strengthen their global brand as well as establish a presence in developed markets. At the same time, building synergies in the developed market will help CMNEs counter some of the potential domestic rivalry arising from their developed country competitors as they enter China. Thus, we argue our results indicate the domestic market protection strategies adopted by the Chinese companies for mitigating competition from their developed market rivals. As CMNEs enter foreign markets, they might also want to establish strategies that protect their existing home markets, and this is relevant since China is rapidly opening its industries to foreign entry and removing restrictions previously observed in its domestic markets. Thus, CMNEs can choose to be strategic and benefit from well-developed institutions in these advanced economies, while still protecting their home market share.

Managers of Chinese companies, also potentially by extension other emerging market firms, can benefit from understanding this nuanced view of investing in advanced markets. These managers can focus on extending their domestic strengths via related industry acquisitions in other developing countries and focus on expanding via vertical integration in the advanced markets. Thus, managers are advised to take into consideration their ownership status and account for both home and host country business environments while making strategic decisions about acquiring in foreign markets. 


\section{References}

Buckley, P. J., Yu, P., Liu, Q., Munjal, S., \& Tao, P. 2016a. The institutional influence on the location strategies of multinational enterprises from emerging economies: evidence from China's cross-border mergers and acquisitions. Management and organization review, 12(3): 425-448.

Chen, Y., \& Young, M. 2010. Cross-border mergers and acquisitions by Chinese listed companies: A principal-principal perspective. Asia Pacific Journal of Management, 27(3): 523-539.

Cui, L., \& Jiang, F. 2012. State ownership effect on firms' FDI ownership decisions under institutional pressure: A study of Chinese outward-investing firms. Journal of International Business Studies, 43(3): 264-284.

Erdener, C., \& Shapiro, D. M. 2005. The internationalization of Chinese family enterprises and Dunning's eclectic MNE paradigm. Management and organization review, 1(3): 411-436.

Huang, X., \& Renyong, C. 2014. Chinese Private Firms' Outward Foreign Direct Investment: Does Firm Ownership and Size Matter? Thunderbird international business review, 56(5): 393-406.

Nicholson, R. R., \& Salaber, J. 2013. The motives and performance of cross-border acquirers from emerging economies: Comparison between Chinese and Indian firms. International Business Review, 22(6): 963-980.

Lu, J., Liu, X., \& Wang, H. 2011. Motives for outward FDI of Chinese private firms: Firm resources, industry dynamics, and government policies. Management and organization review, 7(2): 223-248.

Ramamurti, R. 2008. What Have We Learned About Emerging-Market MNEs? In Ramamurti, R., Singh, J. V. (Ed.), Emerging multinationals in emerging markets Cambridge UK: Cambridge University Press. Tallman, S., \& Li, J. 1996. Effects of international diversity and product diversity on the performance of multinational firms. Academy of Management Journal, 39(1): 179-196.

Lu, J. W., \& Beamish, P. W. 2004. International diversification and firm performance: The S-curve hypothesis. Academy of Management Journal, 47(4): 598-609.

Oesterle, M.-J., Richta, H. N., \& Fisch, J. H. 2013. The influence of ownership structure on internationalization. International Business Review, 22(1): 187-201.

Child, J., \& Marinova, S. 2014. The Role of Contextual Combinations in the Globalization of Chinese Firms. Management and organization review, 10(3): 347-371.

Meyer, K. E., \& Thaijongrak, O. 2013. The dynamics of emerging economy MNEs: How the internationalization process model can guide future research. Asia Pacific Journal of Management, 30(4): 1125-1153.

Rui, H., \& Yip, G. S. 2008. Foreign acquisitions by Chinese firms: A strategic intent perspective. Journal of World Business, 43(2): 213-226.

Choi, Y. R., Yoshikawa, T., Zahra, S. A., \& Han, B. H. 2014. Market-oriented institutional change and R\&D investments: Do business groups enhance advantage? Journal of World Business, 49(4): 466-475. Luo, Y., \& Tung, R. 2007. International expansion of emerging market enterprises: A springboard perspective. Journal of International Business Studies, 38(4): 481-498.

Datta, D. K., Pinches, G. E., \& Narayanan, V. K. 1992. FACTORS INFLUENCING WEALTH CREATION FROM MERGERS AND ACQUISITIONS: A META-ANALYSIS. Strategic Management Journal, 13(1): 67-84.

Cartwright, S., \& Schoenberg, R. 2006. Thirty years of mergers and acquisitions research: Recent advances and future opportunities. British Journal of Management, 17(S1): S1-S5.

Hautz, J., Mayer, M. C., \& Stadler, C. 2013. Ownership identity and concentration: A study of their joint impact on corporate diversification. British Journal of Management, 24(1): 102-126.

Liu, Y., Li, Y., \& Xue, J. 2011. Ownership, strategic orientation and internationalization in emerging markets. Journal of World Business, 46(3): 381-393.

Dietz, M. C., Orr, G., \& Xing, J. 2008. How Chinese companies can succeed abroad. McKinsey Quarterly, 3: 22.

Khanna, T., \& Palepu, K. 2000. The future of business groups in emerging markets: Long-run evidence from Chile. Academy of Management Journal, 43(3): 268-285.

Berrill, J. 2015. Are the World's Largest Firms Regional or Global? Thunderbird international business review, 57(2): 87-101. 
Child, J., \& Rodrigues, S. B. 2005. The Internationalization of Chinese Firms: A Case for Theoretical Extension? Management and organization review, 1(3): 381-410.

Lane, P. J., Cannella Jr, A. A., \& Lubatkin, M. H. 1998. Agency problems as antecedents to unrelated mergers and diversification: Amihud and Lev reconsidered. Strategic Management Journal: 555-578. Milhaupt, C. J., \& Zheng, W. 2014. Beyond ownership: state capitalism and the Chinese firm.

Ramaswamy, K., Li, M., \& Veliyath, R. 2002. Variations in ownership behavior and propensity to diversify: A study of the Indian corporate context. Strategic Management Journal, 23(4): 345-358.

Tihanyi, L., Johnson, R. A., Hoskisson, R. E., \& Hitt, M. A. 2003. Institutional ownership differences and international diversification: The effects of boards of directors and technological opportunity. Academy of Management Journal, 46(2): 195-211.

Lester, R. H., Hillman, A., Zardkoohi, A., \& Cannella, A. A. 2008. Former government officials as outside directors: The role of human and social capital. Academy of Management Journal, 51(5): 999-1013.

Lin, C., \& Su, D. 2008. Industrial diversification, partial privatization and firm valuation: Evidence from publicly listed firms in China. Journal of Corporate Finance, 14(4): 405-417.

Inoue, C. F., Lazzarini, S. G., \& Musacchio, A. 2013. Leviathan as a minority shareholder: Firm-level implications of state equity purchases. Academy of Management Journal, 56(6): 1775-1801.

Ralston, D. A., Terpstra-Tong, J., Terpstra, R. H., Wang, X., \& Egri, C. 2006. Today's state-owned enterprises of China: are they dying dinosaurs or dynamic dynamos? Strategic Management Journal, 27(9): 825-843.

Li, R., \& Cheong, K.-C. 2017. Huawei and ZTE in Malaysia: The Localisation of Chinese Transnational Enterprises. Journal of Contemporary Asia, 47(5): 752-773.

Cai, K. G. 1999. Outward foreign direct investment: A novel dimension of China's integration into the regional and global economy. China Quarterly, 160(4): 856-880.

Deng, P. 2007. Investing for strategic resources and its rationale: The case of outward FDI from Chinese companies. Business Horizons, 50(1): 71-81.

Chen, C., \& Findlay, C. 2003. A Review of Cross-border Mergers and Acquisitions in APEC. Asian-Pacific Economic Literature, 17(2): 14-38.

Luo, Y., Xue, Q., \& Han, B. 2010. How emerging market governments promote outward FDI: Experience from China. Journal of World Business, 45(1): 68-79.

Singh, D. A. 2009. Export performance of emerging market firms. International Business Review, 18(4): 321-330.

Sun, S. L., Peng, M. W., Ren, B., \& Yan, D. 2012. A comparative ownership advantage framework for cross-border M\&As: the rise of Chinese and Indian MNEs. Journal of World Business, 47(1): 4-16.

Wang, C., Hong, J., Kafouros, M., \& Boateng, A. 2012. What drives outward FDI of Chinese firms? Testing the explanatory power of three theoretical frameworks. International Business Review, 21(3): 425-438.

Qian, Y. 1996. Enterprise reform in China: Agency problems and political control. Economics of Transition, 4(2): 427-447.

Tan, J. 2001. Innovation and risk-taking in a transitional economy: A comparative study of chinese managers and entrepreneurs. Journal of Business Venturing, 16(4): 359-376.

Feng, E. 2017. China tightens rules on state groups' foreign investments Financial Times. Beijing.

Nolan, P. 2002. China and the global business revolution. Cambridge journal of economics, 26(1): 119137.

Khanna, T., \& Rivkin, J. W. 2001. Estimating the performance effects of business groups in emerging markets. Strategic Management Journal, 22(1): 45-74.

Leff, N. H. 1978. Industrial organization and entrepreneurship in the developing countries: The economic groups. Economic Development and Cultural Change: 661-675.

Nolan, P. 2001. China and the global economy: Springer.

Yiu, D. W. 2011. Multinational advantages of Chinese business groups: A theoretical exploration. Management and organization review, 7(2): 249-277. 
Lu, Y., \& Yao, J. 2006. Impact of state ownership and control mechanisms on the performance of group affiliated companies in China. Asia Pacific Journal of Management, 23(4): 485-503.

Kim, H., Hoskisson, R. E., Tihanyi, L., \& Hong, J. 2004. The evolution and restructuring of diversified business groups in emerging markets: The lessons from chaebols in Korea. Asia Pacific Journal of Management, 21(1-2): 25-48.

Maman, D. 2002. The emergence of business groups: Israel and South Korea compared. Organization Studies, 23(5): 737-758.

Gaur, A. S., Kumar, V., \& Singh, D. 2014. Institutions, resources, and internationalization of emerging economy firms. Journal of World Business, 49(1): 12-20.

Almeida, H. V., \& Wolfenzon, D. 2006. A theory of pyramidal ownership and family business groups. The Journal of Finance, 61(6): 2637-2680.

$\mathrm{Ma}, \mathrm{X}$., Yao, X., \& Xi, Y. 2006. Business group affiliation and firm performance in a transition economy: A focus on ownership voids. Asia Pacific Journal of Management, 23(4): 467-483.

Khanna, T., \& Yafeh, Y. 2007. Business groups in emerging markets: Paragons or parasites? Journal of Economic Literature, 45(2): 331-372.

Ramasamy, B., Yeung, M., \& Laforet, S. 2010. China's outward foreign direct investment: Location choice and firm ownership. Journal of World Business.

Singh, D. A., \& Gaur, A. S. 2013. Governance structure, innovation and internationalization: evidence from India. Journal of international management, 19(3): 300-309.

Kumar, V., Gaur, A. S., \& Pattnaik, C. 2012. Product diversification and international expansion of business groups. Management International Review, 52(2): 175-192.

Hahn, D., \& Lee, K. 2006. Chinese business groups: Their origins and development. In Chang, S.-j. (Ed.), Business groups in East Asia: Financial crisis, restructuring, and new growth: 207-231.

Lee, K., \& Woo, W. 2001. Business groups in China: compared with Korean chaebols. In Hooley, R., \& Yoo, J. (Eds.), The post-financial crisis challenges for Asian industrialization: 721-747. Amsterdam: Elsevier Science.

Chen, J. J. 2004. Determinants of capital structure of Chinese-listed companies. Journal of Business Research, 57(12): 1341-1351.

Liu, Q., \& Lu, Z. J. 2007. Corporate governance and earnings management in the Chinese listed companies: A tunneling perspective. Journal of Corporate Finance, 13(5): 881-906.

Pistor, K., \& Xu, C. 2005. Governing stock markets in transition economies: Lessons from China. American Law and Economics Review, 7(1): 184-210.

Xu, N., Xu, X., \& Yuan, Q. 2013. Political connections, financing friction, and corporate investment: Evidence from Chinese listed family firms. European Financial Management, 19(4): 675-702.

Bai, C. E., Lu, J., \& Tao, Z. 2006. Property rights protection and access to bank loans. Economics of Transition, 14(4): 611-628.

Cai, Y. 2002. The Resistance of Chinese Laid-off Workers in the Reform Period. The China Quarterly, 170: 327-344.

Hornby, L. 2017. China expands power of anti-corruption watchdog Financial Times. Beijing.

Gubbi, S., Aulakh, P., Ray, S., Sarkar, M., \& Chittoor, R. 2010. Do international acquisitions by emergingeconomy firms create shareholder value: The case of Indian firms. Journal of International Business Studies, 41(3): 397-418.

Boisot, M., \& Meyer, M. W. 2008. Which way through the open door? Reflections on the internationalization of Chinese firms. Management and organization review, 4(3): 349-365.

De Beule, F., \& Duanmu, J.-L. 2012. Locational determinants of internationalization: A firm-level analysis of Chinese and Indian acquisitions. European Management Journal, 30(3): 264-277.

Alden, C., \& Davies, M. 2006. Chinese multinational corporations in Africa. Africa Institute of South Africa(3-4): 1-11.

Liou, R.-S., Chao, M. C.-H., \& Yang, M. 2016. Emerging economies and institutional quality: Assessing the differential effects of institutional distances on ownership strategy. Journal of World Business, 51(4): 600-611. 
Buckley, P. J., Yu, P., Liu, Q., Munjal, S., \& Tao, P. 2016b. The Institutional Influence on the Location Strategies of Multinational Enterprises from Emerging Economies: Evidence from China's Cross-border Mergers and Acquisitions. Management and organization review.

Rumelt, R. P. 1974. Strategy, structure, and economic performance.

Moeller, S. B., \& Schlingemann, F. P. 2005. Global diversification and bidder gains: A comparison between cross-border and domestic acquisitions. Journal of Banking \& Finance, 29(3): 533-564.

Denis, D., Denis, D., \& Yost, K. 2002. Global diversification, industrial diversification, and firm value. The Journal of Finance, 57(5): 1951-1979.

Shleifer, A., \& Vishny, R. W. 2003. Stock market driven acquisitions. Journal of financial economics, 70(3): 295-311.

Barai, P., \& Mohanty, P. 2014. Role of industry relatedness in performance of Indian acquirers-Long and short run effects. Asia Pacific Journal of Management, 31(4): 1045-1073.

Sun, S. L., Peng, M. W., \& Tan, W. 2017. Institutional relatedness behind product diversification and international diversification. Asia Pacific Journal of Management, 34(2): 339-366.

Nocker, E., Bowen, H. P., Stadler, C., \& Matzler, K. 2016. Capturing relatedness: comprehensive measures based on secondary data. British Journal of Management, 27(1): 197-213.

Li, W., He, A., Lan, H., \& Yiu, D. 2012. Political connections and corporate diversification in emerging economies: Evidence from China. Asia Pacific Journal of Management, 29(3): 799-818.

Neffke, F., Henning, M., \& Boschma, R. 2011. How do regions diversify over time? Industry relatedness and the development of new growth paths in regions. Economic Geography, 87(3): 237-265.

Haleblian, J., \& Finkelstein, S. 1999. The influence of organizational acquisition experience on acquisition performance: A behavioral learning perspective. Administrative Science Quarterly, 44(1): 29-56.

Linn, S. C., \& Switzer, J. A. 2001. Are cash acquisitions associated with better postcombination operating performance than stock acquisitions? Journal of Banking \& Finance, 25(6): 1113-1138.

Lang, L. H. P., Stulz, R. M., \& Walkling, R. A. 1991. A test of the free cash flow hypothesis: The case of bidder returns. Journal of financial economics, 29(2): 315-335.

Liou, R.-S., Rao-Nicholson, R., \& Sarpong, D. forthcoming. What's in a name? Cross-national distances and subsidiary's corporate visual identity change in emerging-market firms' cross-border acquisitions. International Marketing Review.

Ghemawat, P. 2001. Distance still matters. Harvard Business Review, 79(8): 137-147.

Berry, H., Guillén, M. F., \& Zhou, N. 2010. An institutional approach to cross-national distance. Journal of International Business Studies, 41(9): 1460-1480.

Jean, R.-J. B., Tan, D., \& Sinkovics, R. R. 2011. Ethnic ties, location choice, and firm performance in foreign direct investment: A study of Taiwanese business groups FDI in China. International Business Review, 20(6): 627-635.

Zaheer, S., Lamin, A., \& Subramani, M. 2009. Cluster capabilities or ethnic ties? Location choice by foreign and domestic entrants in the services offshoring industry in India. Journal of International Business Studies, 40(6): 944-968.

Buckley, P. J., Forsans, N., \& Munjal, S. 2012. Host-home country linkages and host-home country specific advantages as determinants of foreign acquisitions by Indian firms. International Business Review, 21(5): 878-890.

Hair, J. F., Anderson, R. E., Tatham, R. L., \& William, C. 1998. Black (1998), Multivariate data analysis. Upper Saddle River, NJ: Prentice Hall.

Deng, P. 2009. Why do Chinese firms tend to acquire strategic assets in international expansion? Journal of World Business, 44(1): 74-84.

Toplensky, R. 2017. Syngenta and ChemChina deal to complete by summer, says chief Financial Times. Brussels.

Boubakri, N., Cosset, J.-C., \& Saffar, W. 2013. The role of state and foreign owners in corporate risktaking: Evidence from privatization. Journal of financial economics, 108(3): 641-658. 
Peng, M. W. 2005. Perspectives-from China strategy to global strategy. Asia Pacific Journal of Management, 22(2): 123-141.

Xu, D., Zhou, C., \& Phan, P. H. 2010. A real options perspective on sequential acquisitions in China. Journal of International Business Studies, 41(1): 166-174.

Liu, Y., \& Woywode, M. 2013. Light - Touch Integration of Chinese Cross - Border M\&A: The Influences of Culture and Absorptive Capacity. Thunderbird international business review, 55(4): 469483. 


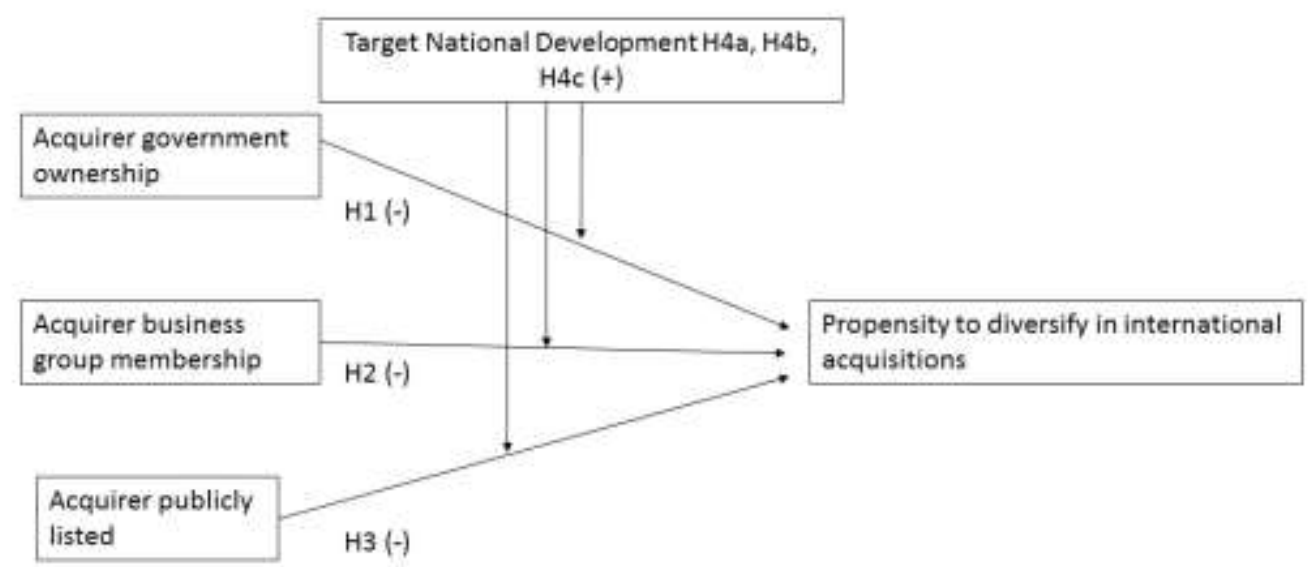

Figure 1. Conceptual Framework of ownership types and propensity to diversify 

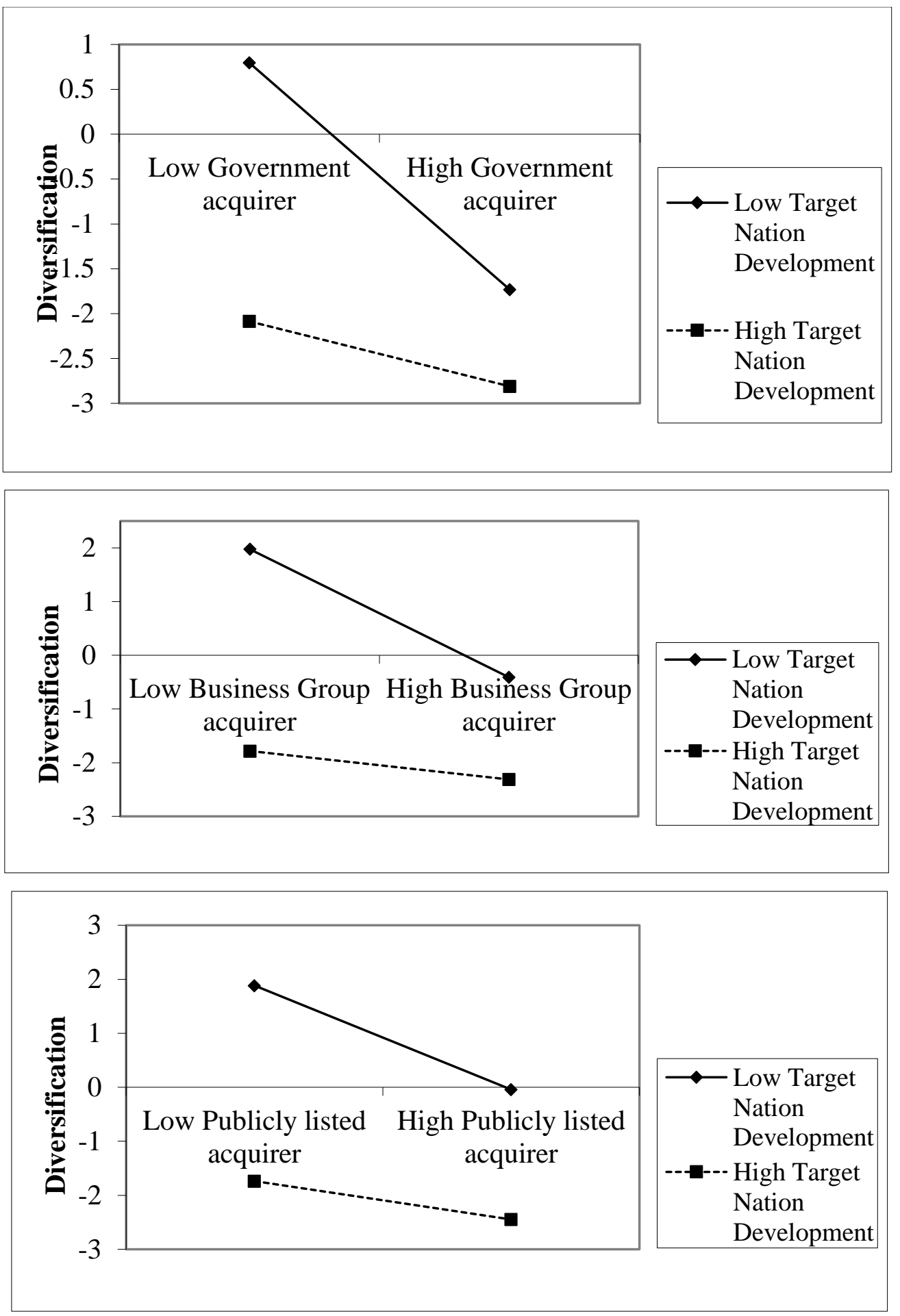

Figure 2. Moderating effect of target national development on the relationship between the Ownership status and propensity to diversify 
Table 1. Country and year-wise distribution of deals

\begin{tabular}{|c|c|c|c|c|c|c|c|c|c|c|c|c|c|c|c|c|c|c|c|c|c|c|c|c|c|}
\hline Target & 198 & 198 & 198 & 199 & 199 & 199 & 199 & 199 & 199 & 199 & 200 & 200 & 200 & 20 & 20 & 200 & 200 & 200 & 200 & 201 & 201 & 201 & 201 & 201 & Grand \\
\hline Nations & 6 & 8 & 9 & 2 & 3 & 4 & 5 & 7 & 8 & 9 & $\mathbf{0}$ & 1 & 2 & 04 & 05 & 6 & 7 & 8 & 9 & $\mathbf{0}$ & 1 & 2 & 3 & 4 & Total \\
\hline Australia & & & & & & & & & 1 & & & & & & & & 2 & 2 & 3 & 2 & 3 & 2 & 2 & & 17 \\
\hline Canada & & & & & & & & & & 1 & & & & 1 & 1 & & 1 & 4 & 2 & 2 & 4 & 1 & & & 17 \\
\hline Germany & & & & & & & & & & & & & & 1 & & & & & & & & & & & 1 \\
\hline Hong Kong & 1 & & 1 & 1 & 2 & 1 & 1 & 3 & & & 5 & 2 & 2 & 3 & 4 & 1 & 1 & 8 & 3 & 4 & 3 & 2 & 1 & 2 & 51 \\
\hline Israel & & & & & & & & & & & & & & & & & & & & 1 & & & & & 1 \\
\hline Japan & & & & & & & & & & & & & & 1 & & 1 & & & & & & & & & 2 \\
\hline Netherlands & & & & & & & & & & & & & & & 1 & & & & & & & & & & 1 \\
\hline \multicolumn{26}{|l|}{ New } \\
\hline Zealand & & & & & & & 1 & & & & & & & & & & & & & & & & & & 1 \\
\hline Russian Fed & & & & & & & & & & & & & & & & 1 & & & & & & & & & 1 \\
\hline Singapore & & & & & & & & & & & & & & & & & 1 & 1 & 2 & 1 & 1 & & & & 6 \\
\hline South Korea & & & & & & & & & & & & & & 1 & & & & 1 & & & & & & & 2 \\
\hline \multicolumn{26}{|l|}{ South } \\
\hline Africa & & & & & & & & & & & & & & & & & & & & & 1 & & & & 1 \\
\hline Switzerland & & & & & & & & & & & & & & & & & & & & & 1 & & & & 1 \\
\hline Thailand & & & & & & & & & & & & & & & & & & & 1 & 1 & & & & & 2 \\
\hline \multicolumn{26}{|l|}{ United } \\
\hline Kingdom & & & & & & & & & & & & & & & 1 & & 2 & & & & & 1 & 1 & & 5 \\
\hline United & & 1 & & & & & & & & & & & & & & & & & & & & & & & \\
\hline States & & & & & & & & 1 & 1 & & & & & & 1 & & 1 & 3 & 2 & 3 & 1 & 1 & 1 & & 16 \\
\hline Grand & & 1 & 1 & 1 & & & & & & & & & & & & & & & & & & & & & \\
\hline Total & 1 & & & & 2 & 1 & 2 & 4 & 2 & 1 & 5 & 2 & 2 & 7 & 8 & 3 & 7 & 19 & 13 & 14 & 14 & 7 & 5 & 2 & 125 \\
\hline
\end{tabular}


Table 2. Definition and source of variables

\begin{tabular}{|c|c|c|}
\hline Variable name & Definition & Source \\
\hline Diversification & $\begin{array}{l}\text { Dummy = } 1 \text { if target belongs to different } \\
\text { industry than the bidder when compared } \\
\text { at } 4 \text {-digit level, } 0 \text { otherwise }\end{array}$ & SDC Platinum database \\
\hline Acquirer government & $\begin{array}{l}\text { Dummy = } 1 \text { if fully government-owned } \\
\text { or government majority stakeholder, } 0 \\
\text { otherwise }\end{array}$ & SDC Platinum database \\
\hline $\begin{array}{l}\text { Acquirer business } \\
\text { group }\end{array}$ & $\begin{array}{l}\text { Dummy }=1 \text { if company is part of a } \\
\text { business group, } 0 \text { otherwise }\end{array}$ & SDC Platinum database \\
\hline Acquirer publicly listed & $\begin{array}{l}\text { Dummy }=1 \text { if acquirer is a public } \\
\text { company, } 0 \text { otherwise }\end{array}$ & SDC Platinum database \\
\hline $\begin{array}{l}\text { Target national } \\
\text { development }\end{array}$ & $\begin{array}{l}\text { Dummy = } 1 \text { if World Bank lists target } \\
\text { country as developed country, , } 0 \\
\text { otherwise }\end{array}$ & World Bank \\
\hline Book/price Ratio & Bidder's price-to-book ratio of the target & SDC Platinum database \\
\hline Market seeking & $\begin{array}{l}\text { Dummy }=1 \text { if } \operatorname{GDP}(\text { target })> \\
\text { GDP(China }),, 0 \text { otherwise }\end{array}$ & World Bank \\
\hline Percentage acquired & $\begin{array}{l}\text { Percentage of shares acquired in the } \\
\text { transaction }\end{array}$ & SDC Platinum database \\
\hline Cash & $\begin{array}{l}\text { Dummy = } 1 \text { if cash-financed deal, } 0 \\
\text { otherwise }\end{array}$ & SDC Platinum database \\
\hline Historical links & $\begin{array}{l}\text { Dummy }=1 \text { if country has historical } \\
\text { links with China, } 0 \text { otherwise }\end{array}$ & $\begin{array}{l}\text { National } \\
\text { website, newspaper, } \\
\text { country information } \\
\text { website like the CIA } \\
\text { website }\end{array}$ \\
\hline Legal distance & $\begin{array}{l}\text { Target legal and regulatory framework } \\
\text { index/ Acquirer legal and regulatory } \\
\text { framework index }\end{array}$ & $\begin{array}{l}\text { legal and regulatory } \\
\text { framework file from } \\
\text { IMD WYC executive } \\
\text { survey }\end{array}$ \\
\hline Economic distance & $\begin{array}{l}\text { The composite index for economic } \\
\text { freedom }\end{array}$ & Heritage Foundation \\
\hline
\end{tabular}




\begin{tabular}{|l|l|l|}
\hline \multirow{2}{*}{ Foreign exchange } & $\begin{array}{l}\text { The relative strength of the exchange } \\
\text { rate is calculated as the deviation of the } \\
\text { foreign exchange rate at announcement } \\
\text { date from its 12-month average. }\end{array}$ & \\
\hline
\end{tabular}


Table 3. Descriptive statistics

\begin{tabular}{|c|c|c|c|c|c|c|c|}
\hline \multirow{2}{*}{$\begin{array}{l}\text { Variable } \\
\text { Acquirer government }\end{array}$} & \multicolumn{2}{|c|}{$\begin{array}{l}\text { Undiversified } \\
\qquad(\mathrm{n}=30) \\
\text { Std. } \\
\text { Mean Dev. }\end{array}$} & \multicolumn{2}{|c|}{$\begin{array}{c}\text { Diversified } \\
(\mathrm{n}=62)\end{array}$} & \multicolumn{3}{|c|}{$\begin{array}{c}\text { Mean Difference ( } t \text { - } \\
\text { statistics) }\end{array}$} \\
\hline & 0.44 & 0.44 & 0.48 & 0.47 & 0.06 & & 0.706 \\
\hline Acquirer business group & 0.40 & 0.50 & 0.17 & 0.37 & 0.26 & $* * *$ & 2.8416 \\
\hline Acquirer publicly listed & 0.43 & 0.50 & 0.14 & 0.35 & 0.33 & $* * *$ & 3.5645 \\
\hline \multicolumn{8}{|l|}{ Target national } \\
\hline development & 0.46 & 0.51 & 0.49 & 0.50 & & & \\
\hline Book/price Ratio & 3.45 & 7.38 & 4.34 & 28.21 & & & \\
\hline Market seeking & 0.74 & 0.44 & 0.72 & 0.45 & & & \\
\hline Percentage acquired & 60.92 & 33.80 & 59.59 & 32.06 & & & \\
\hline Cash & 0.63 & 0.49 & 0.53 & 0.50 & & & \\
\hline Historical links & 0.46 & 0.51 & 0.47 & 0.50 & & & \\
\hline Legal distance & 1.31 & 0.32 & 1.30 & 0.32 & & & \\
\hline Economic distance & 1.56 & 0.18 & 1.58 & 0.14 & & & \\
\hline Foreign exchange & 3.30 & 13.27 & 2.62 & 16.36 & & & \\
\hline
\end{tabular}

*** $\mathrm{p}<0.01$, non-missing values included in this table 
Table 4. Pearson correlation coefficients

\begin{tabular}{|c|c|c|c|c|c|c|c|c|c|c|c|c|c|c|c|}
\hline & Variable & Mean & S.D. & 1 & 2 & 3 & 4 & 5 & 6 & 7 & 8 & 9 & 10 & 11 & 12 \\
\hline 1 & Diversification & 0.68 & 0.05 & 1 & & & & & & & & & & & \\
\hline 2 & $\begin{array}{l}\text { Acquirer } \\
\text { government }\end{array}$ & 0.69 & 0.46 & -0.064 & 1 & & & & & & & & & & \\
\hline 3 & $\begin{array}{l}\text { Acquirer } \\
\text { business group }\end{array}$ & 0.23 & 0.42 & $-0.248 * * *$ & $-0.337 * * *$ & 1 & & & & & & & & & \\
\hline 4 & $\begin{array}{l}\text { Acquirer publicly } \\
\text { listed }\end{array}$ & 0.25 & 0.41 & $-0.306 * * *$ & 0.147 & -0.023 & 1 & & & & & & & & \\
\hline 5 & $\begin{array}{l}\text { Target national } \\
\text { development }\end{array}$ & 0.48 & 0.50 & 0.029 & -0.096 & -0.111 & -0.017 & 1 & & & & & & & \\
\hline 6 & Book/price Ratio & 4.26 & 2.44 & 0.017 & 0.06 & -0.051 & 0.165 & -0.0567 & 1 & & & & & & \\
\hline 7 & Market seeking & 0.71 & 0.05 & -0.021 & -0.13 & 0.123 & -0.06 & $-0.636 * * *$ & 0.057 & 1 & & & & & \\
\hline 8 & $\begin{array}{l}\text { Percentage } \\
\text { acquired }\end{array}$ & 59.13 & 3.31 & -0.018 & -0.131 & -0.097 & -0.061 & 0.061 & 0.144 & $-0.303 * * *$ & 1 & & & & \\
\hline 9 & Cash & 0.63 & 0.05 & -0.086 & 0.115 & -0.124 & 0.128 & -0.019 & -0.124 & $-0.288 * * *$ & 0.088 & 1 & & & \\
\hline 10 & Historical links & 0.45 & 0.05 & 0.009 & 0.057 & 0.135 & $-0.192 * *$ & $0.670 * * *$ & -0.128 & $0.569 * * *$ & $-0.437 * * *$ & -0.145 & 1 & & \\
\hline 11 & Legal distance & 1.34 & 0.03 & -0.02 & 0.116 & -0.016 & -0.099 & $0.381 * * *$ & $-0.328 * * *$ & -0.05 & $-0.407 * * *$ & $0.3 * * *$ & $0.288 * * *$ & 1 & \\
\hline 12 & $\begin{array}{l}\text { Economic } \\
\text { distance }\end{array}$ & 1.58 & 0.01 & 0.069 & 0.089 & 0.083 & $-0.222 * *$ & $0.414 * * *$ & $-0.455^{* * *}$ & 0.129 & $-0.414 * * *$ & 0.063 & $0.561 * * *$ & $0.717 * * *$ & 1 \\
\hline 13 & $\begin{array}{l}\text { Foreign } \\
\text { exchange }\end{array}$ & 3.10 & 1.72 & -0.020 & -0.086 & -0.067 & $0.153 * * *$ & -0.137 & 0.078 & 0.105 & $-0.161^{*}$ & 0.015 & -0.082 & $-0.337 * * *$ & $-0.281 * * *$ \\
\hline
\end{tabular}

$* * * \mathrm{p}<0.01, * * \mathrm{p}<0.05, * \mathrm{p}<0.1$ 
Table 5. Probit Regression Results for dependent variable Diversification.

\begin{tabular}{|c|c|c|c|c|c|c|c|c|}
\hline & $\begin{array}{c}(1) \\
\text { Controls } \\
\end{array}$ & $\begin{array}{c}(2) \\
\text { Direct effect }\end{array}$ & $\begin{array}{c}(3) \\
\text { Direct effect }\end{array}$ & $\begin{array}{c}(4) \\
\text { Direct effect }\end{array}$ & $\begin{array}{c}(5) \\
\text { Interaction } \\
\end{array}$ & $\begin{array}{c}(6) \\
\text { Interaction } \\
\end{array}$ & $\begin{array}{c}(7) \\
\text { Interaction } \\
\end{array}$ & $\begin{array}{c}(8) \\
\text { Full model } \\
\end{array}$ \\
\hline \multicolumn{9}{|l|}{ VARIABLES } \\
\hline \multicolumn{9}{|l|}{ Main effects } \\
\hline Acquirer government (H1) & & $\begin{array}{c}-1.000 * * * \\
(0.333)\end{array}$ & & & $\begin{array}{c}-1.633 * * * \\
(0.452)\end{array}$ & & & $\begin{array}{c}-2.694 * * * \\
(0.750)\end{array}$ \\
\hline Acquirer business group (H2) & & & $\begin{array}{c}-0.992 * * * \\
(0.362)\end{array}$ & & & $\begin{array}{c}-1.533 * * * \\
(0.560)\end{array}$ & & $\begin{array}{c}-2.766 * * * \\
(0.675)\end{array}$ \\
\hline Acquirer publicly listed (H3) & & & & $\begin{array}{c}-1.459 * * * \\
(0.406)\end{array}$ & & & $\begin{array}{c}-2.435^{* * * *} \\
(0.648)\end{array}$ & $\begin{array}{c}-2.269 * * * \\
(0.775)\end{array}$ \\
\hline \multicolumn{9}{|l|}{ Interaction terms } \\
\hline Host country development & & & & & $\begin{array}{l}-1.392 \\
(0.856)\end{array}$ & $\begin{array}{l}-0.376 \\
(0.720)\end{array}$ & $\begin{array}{l}-1.194 \\
(0.801)\end{array}$ & $\begin{array}{c}-3.328 * * * \\
(1.287)\end{array}$ \\
\hline Acquirer government $*$ Host country development $(\mathrm{H} 4 \mathrm{a})$ & & & & & $\begin{array}{l}1.417 * * \\
(0.670)\end{array}$ & & & $\begin{array}{l}1.946^{* *} \\
(1.111)\end{array}$ \\
\hline Acquirer business group $*$ Host country development $(\mathrm{H} 4 \mathrm{~b})$ & & & & & & $\begin{array}{l}1.316^{*} \\
(0.754)\end{array}$ & & $\begin{array}{c}2.181 * * \\
(1.070)\end{array}$ \\
\hline Acquirer publicly listed $*$ Host country development $(\mathrm{H} 4 \mathrm{c})$ & & & & & & & $\begin{array}{l}1.665^{* *} \\
(0.778)\end{array}$ & $\begin{array}{c}1.447 \\
(0.936)\end{array}$ \\
\hline \multicolumn{9}{|l|}{ Controls } \\
\hline Percent acquired & $\begin{array}{c}0.0008 \\
(0.0057)\end{array}$ & $\begin{array}{l}-0.00178 \\
(0.00587)\end{array}$ & $\begin{array}{l}-0.00171 \\
(0.00576)\end{array}$ & $\begin{array}{l}-0.00472 \\
(0.00598)\end{array}$ & $\begin{array}{l}4.72 \mathrm{e}-05 \\
(0.00635)\end{array}$ & $\begin{array}{l}-0.00338 \\
(0.00614)\end{array}$ & $\begin{array}{l}-0.00479 \\
(0.00631)\end{array}$ & $\begin{array}{l}-0.00874 \\
(0.00780)\end{array}$ \\
\hline Cash & $\begin{array}{l}-0.2866 \\
0.3294\end{array}$ & $\begin{array}{l}-0.139 \\
(0.333)\end{array}$ & $\begin{array}{c}-0.347 \\
(0.353)\end{array}$ & $\begin{array}{l}-0.0453 \\
(0.356)\end{array}$ & $\begin{array}{l}-0.359 \\
(0.357)\end{array}$ & $\begin{array}{c}-0.373 \\
(0.381)\end{array}$ & $\begin{array}{l}0.0425 \\
(0.369)\end{array}$ & $\begin{array}{l}-0.110 \\
(0.422)\end{array}$ \\
\hline Book/price Ratio & $\begin{array}{l}0.0109 * \\
(0.0065)\end{array}$ & $\begin{array}{c}0.0127 * \\
(0.00663)\end{array}$ & $\begin{array}{c}0.0109 * \\
(0.00621)\end{array}$ & $\begin{array}{c}0.00870 \\
(0.00636)\end{array}$ & $\begin{array}{l}0.0135 * * \\
(0.00643)\end{array}$ & $\begin{array}{c}0.0101 \\
(0.00622)\end{array}$ & $\begin{array}{c}0.00979 \\
(0.00641)\end{array}$ & $\begin{array}{l}0.0144 * * \\
(0.00602)\end{array}$ \\
\hline Market seeking & $\begin{array}{l}-0.2600 \\
(0.4350)\end{array}$ & $\begin{array}{l}-0.630 \\
(0.471)\end{array}$ & $\begin{array}{l}-0.205 \\
(0.447)\end{array}$ & $\begin{array}{l}-0.189 \\
(0.431)\end{array}$ & $\begin{array}{l}-0.334 \\
(0.577)\end{array}$ & $\begin{array}{l}-0.413 \\
(0.516)\end{array}$ & $\begin{array}{l}-0.184 \\
(0.525)\end{array}$ & $\begin{array}{l}-0.875 \\
(0.741)\end{array}$ \\
\hline Historical links & $\begin{array}{l}-0.1824 \\
(0.5316)\end{array}$ & $\begin{array}{l}-0.0353 \\
(0.519)\end{array}$ & $\begin{array}{l}-0.155 \\
(0.569)\end{array}$ & $\begin{array}{l}-0.577 \\
(0.544)\end{array}$ & $\begin{array}{l}-0.467 \\
(0.606)\end{array}$ & $\begin{array}{l}-0.0557 \\
(0.640)\end{array}$ & $\begin{array}{l}-1.241 * \\
(0.699)\end{array}$ & $\begin{array}{l}-1.430^{*} \\
(0.786)\end{array}$ \\
\hline Legal distance & $\begin{array}{c}0.3336 \\
(1.1764)\end{array}$ & $\begin{array}{c}0.627 \\
(1.243)\end{array}$ & $\begin{array}{l}0.0148 \\
(1.173)\end{array}$ & $\begin{array}{c}0.607 \\
(1.174)\end{array}$ & $\begin{array}{c}0.117 \\
(1.524)\end{array}$ & $\begin{array}{l}-0.236 \\
(1.504)\end{array}$ & $\begin{array}{l}-0.908 \\
(1.695)\end{array}$ & $\begin{array}{l}-1.179 \\
(2.228)\end{array}$ \\
\hline Economic distance & $\begin{array}{c}1.6320 \\
(2.2683)\end{array}$ & $\begin{array}{c}1.030 \\
(2.416)\end{array}$ & $\begin{array}{c}1.497 \\
(2.208)\end{array}$ & $\begin{array}{c}0.606 \\
(2.159)\end{array}$ & $\begin{array}{c}2.318 \\
(2.788)\end{array}$ & $\begin{array}{c}1.356 \\
(2.666)\end{array}$ & $\begin{array}{c}3.059 \\
(2.927)\end{array}$ & $\begin{array}{c}3.708 \\
(3.459)\end{array}$ \\
\hline $\begin{array}{l}\text { Foreign exchange } \\
\text { rate change }\end{array}$ & $\begin{array}{c}0.0066 \\
(0.0093)\end{array}$ & $\begin{array}{c}0.00397 \\
(0.00897)\end{array}$ & $\begin{array}{c}0.00223 \\
(0.00947)\end{array}$ & $\begin{array}{c}0.00723 \\
(0.00976)\end{array}$ & $\begin{array}{l}-0.00141 \\
(0.0103)\end{array}$ & $\begin{array}{c}-0.000841 \\
(0.0107)\end{array}$ & $\begin{array}{l}0.00204 \\
(0.0110)\end{array}$ & $\begin{array}{l}-0.0147 \\
(0.0124)\end{array}$ \\
\hline
\end{tabular}




\begin{tabular}{|c|c|c|c|c|c|c|c|c|}
\hline Year dummies & Yes & Yes & Yes & Yes & Yes & Yes & Yes & Yes \\
\hline \multirow[t]{2}{*}{ Constant } & -2.4663 & -1.198 & -1.407 & -0.943 & -1.679 & -0.470 & -1.446 & 1.364 \\
\hline & $(2.5589)$ & (2.607) & $(2.522)$ & $(2.425)$ & $(2.855)$ & (2.569) & $(2.507)$ & (3.027) \\
\hline Observations & 92 & 92 & 92 & 92 & 92 & 92 & 92 & 92 \\
\hline Log likelihood & -51.63 & -48.40 & -48.29 & -45.08 & -46.97 & -47.01 & -43.29 & -33.79 \\
\hline Pseudo R square & 0.131 & 0.186 & 0.188 & 0.242 & 0.210 & 0.209 & 0.272 & 0.431 \\
\hline
\end{tabular}

Robust standard errors in parentheses

$* * * \mathrm{p}<0.01, * * \mathrm{p}<0.05, * \mathrm{p}<0.1$ 
Table 6. Robustness check - Probit Regression Results for diversification at 3-digit level.

\begin{tabular}{|c|c|c|c|c|c|c|c|}
\hline VARIABLES & $\begin{array}{c}\text { (1) } \\
\text { Direct effect }\end{array}$ & $\begin{array}{c}(2) \\
\text { Direct effect }\end{array}$ & $\begin{array}{c}\text { (3) } \\
\text { Direct effect }\end{array}$ & $\begin{array}{c}(4) \\
\text { Interaction }\end{array}$ & $\begin{array}{c}(5) \\
\text { Interaction }\end{array}$ & $\begin{array}{c}(6) \\
\text { Interaction } \\
\end{array}$ & $\begin{array}{c}(7) \\
\text { Full model }\end{array}$ \\
\hline \multicolumn{8}{|l|}{ Main effects } \\
\hline Acquirer government (H1) & $\begin{array}{c}-0.959 * * * \\
(0.341)\end{array}$ & & & $\begin{array}{c}-2.292 * * * \\
(0.620)\end{array}$ & & & $\begin{array}{c}-5.159 * * * \\
(0.956)\end{array}$ \\
\hline Acquirer business group (H2) & & $\begin{array}{c}-0.981 * * \\
(0.389)\end{array}$ & & & $\begin{array}{c}-1.410 * * \\
(0.630)\end{array}$ & & $\begin{array}{c}-4.506^{* * * *} \\
(0.610)\end{array}$ \\
\hline Acquirer publicly listed (H3) & & & $\begin{array}{c}-1.456 * * * \\
(0.430)\end{array}$ & & & $\begin{array}{c}-2.927 * * * \\
(0.923)\end{array}$ & $\begin{array}{c}-1.928 * * \\
(0.963)\end{array}$ \\
\hline \multicolumn{8}{|l|}{ Interaction terms } \\
\hline Host country development & & & & $\begin{array}{c}-5.635 * * * \\
(1.947)\end{array}$ & $\begin{array}{l}-3.130^{*} \\
(1.702)\end{array}$ & $\begin{array}{c}-5.620 * * * \\
(1.894)\end{array}$ & $\begin{array}{c}-9.949 * * * \\
(2.108)\end{array}$ \\
\hline $\begin{array}{l}\text { Acquirer government } * \text { Host } \\
\text { country development }(\mathrm{H} 4 \mathrm{a})\end{array}$ & & & & $\begin{array}{c}1.977 * * * \\
(0.759)\end{array}$ & & & $\begin{array}{l}3.627 * * \\
(1.459)\end{array}$ \\
\hline $\begin{array}{l}\text { Acquirer business group } * \text { Host } \\
\text { country development }(\mathrm{H} 4 \mathrm{~b})\end{array}$ & & & & & $\begin{array}{c}0.927 \\
(0.808)\end{array}$ & & $\begin{array}{l}3.061 * * \\
(1.214)\end{array}$ \\
\hline $\begin{array}{l}\text { Acquirer publicly listed } * \text { Host } \\
\text { country development }(\mathrm{H} 4 \mathrm{c})\end{array}$ & & & & & & $\begin{array}{l}2.104 * * \\
(0.992)\end{array}$ & $\begin{array}{c}0.967 \\
(1.133)\end{array}$ \\
\hline Controls & & & & & & & \\
\hline Percent acquired & $\begin{array}{l}-0.00685 \\
(0.00653)\end{array}$ & $\begin{array}{l}-0.00506 \\
(0.00649)\end{array}$ & $\begin{array}{l}-0.00686 \\
(0.00645)\end{array}$ & $\begin{array}{l}-0.00731 \\
(0.00736)\end{array}$ & $\begin{array}{l}-0.00522 \\
(0.00647)\end{array}$ & $\begin{array}{l}-0.00672 \\
(0.00660)\end{array}$ & $\begin{array}{c}-0.0138 \\
(0.00869)\end{array}$ \\
\hline Cash & $\begin{array}{l}0.0701 \\
(0.350)\end{array}$ & $\begin{array}{l}-0.226 \\
(0.380)\end{array}$ & $\begin{array}{l}0.0584 \\
(0.374)\end{array}$ & $\begin{array}{l}-0.316 \\
(0.366)\end{array}$ & $\begin{array}{l}-0.432 \\
(0.405)\end{array}$ & $\begin{array}{l}0.0476 \\
(0.380)\end{array}$ & $\begin{array}{l}-0.158 \\
(0.482)\end{array}$ \\
\hline Book/price Ratio & $\begin{array}{c}0.0120^{*} \\
(0.00659)\end{array}$ & $\begin{array}{c}0.0101 \\
(0.00619)\end{array}$ & $\begin{array}{c}0.00910 \\
(0.00619)\end{array}$ & $\begin{array}{l}-0.00121 \\
(0.0103)\end{array}$ & $\begin{array}{l}-0.00191 \\
(0.00970)\end{array}$ & $\begin{array}{l}-0.00742 \\
(0.0114)\end{array}$ & $\begin{array}{l}-0.0154 \\
(0.0132)\end{array}$ \\
\hline Market seeking & $\begin{array}{l}-0.568 \\
(0.478)\end{array}$ & $\begin{array}{l}-0.153 \\
(0.447)\end{array}$ & $\begin{array}{l}-0.137 \\
(0.445)\end{array}$ & $\begin{array}{c}-1.735 * * \\
(0.790)\end{array}$ & $\begin{array}{c}-1.388^{*} \\
(0.732)\end{array}$ & $\begin{array}{c}-1.513 * * \\
(0.741)\end{array}$ & $\begin{array}{c}-2.621 * * * \\
(0.905)\end{array}$ \\
\hline Historical links & $\begin{array}{c}0.617 \\
(0.561)\end{array}$ & $\begin{array}{c}0.465 \\
(0.613)\end{array}$ & $\begin{array}{c}-0.0592 \\
(0.631)\end{array}$ & $\begin{array}{c}0.760 \\
(0.803)\end{array}$ & $\begin{array}{c}0.831 \\
(0.767)\end{array}$ & $\begin{array}{l}-0.316 \\
(0.844)\end{array}$ & $\begin{array}{c}0.196 \\
(0.971)\end{array}$ \\
\hline Legal distance & $\begin{array}{c}1.172 \\
(1.311)\end{array}$ & $\begin{array}{c}0.720 \\
(1.312)\end{array}$ & $\begin{array}{l}1.287 \\
(1.300)\end{array}$ & $\begin{array}{l}-1.382 \\
(1.792)\end{array}$ & $\begin{array}{l}-0.873 \\
(1.629)\end{array}$ & $\begin{array}{l}-1.986 \\
(1.763)\end{array}$ & $\begin{array}{l}-1.905 \\
(2.258)\end{array}$ \\
\hline Economic distance & $\begin{array}{l}-3.115 \\
(3.018)\end{array}$ & $\begin{array}{l}-2.718 \\
(3.081)\end{array}$ & $\begin{array}{l}-2.853 \\
(3.093)\end{array}$ & $\begin{array}{l}-9.360 \\
(5.693)\end{array}$ & $\begin{array}{c}-8.099 \\
(5.080)\end{array}$ & $\begin{array}{l}-9.784 \\
(6.269)\end{array}$ & $\begin{array}{c}-14.75 * * \\
(7.149)\end{array}$ \\
\hline Foreign exchange & $-0.511 * *$ & $-0.431 * *$ & -0.375 & $-1.834 * * *$ & $-1.295^{* *}$ & $-1.847 * * *$ & $-1.941 * * *$ \\
\hline
\end{tabular}


rate change

Year dummies

Constant

Observations

Log likelihood

Pseudo R square
(0.216)

4.853

Yes

(3.808)

92

$-45.55$

0.241
(0.205)

4.463

Yes

(3.932)

92

$-45.26$

0.246
$(0.245) \quad(0.670)$

$3.553 \quad 24.80$ **

(3.831)

92

92

0.295

Robust standard errors in parentheses

Robust standard errors in parenth
$* * * \mathrm{p}<0.01, * * \mathrm{p}<0.05, * \mathrm{p}<0.1$

\begin{tabular}{ccc}
$(0.632)$ & $(0.641)$ & $(0.509)$ \\
$19.03 *$ & $25.57 * *$ & $40.00 * * *$ \\
Yes & Yes & Yes \\
$(9.782)$ & $(11.11)$ & $(11.86)$ \\
92 & 92 & 92 \\
-42.47 & -37.62 & -27.37 \\
0.293 & 0.373 & 0.544 \\
\hline
\end{tabular}


Table 7. Robustness check - Probit Regression Results for diversification at 2-digit and 1-digit levels.

\begin{tabular}{|c|c|c|c|c|c|c|c|c|c|c|c|c|c|c|}
\hline \multirow{3}{*}{ VARIABLES } & (1) & (2) & (3) & (4) & $(5)$ & (6) & (7) & (8) & (9) & $(10)$ & $(11)$ & $(12)$ & (13) & (14) \\
\hline & \multicolumn{7}{|c|}{ 2-digit diversification } & \multicolumn{7}{|c|}{ 1-digit diversification } \\
\hline & $\begin{array}{c}\text { Direct } \\
\text { effect }\end{array}$ & $\begin{array}{l}\text { Direct } \\
\text { effect }\end{array}$ & $\begin{array}{l}\text { Direct } \\
\text { effect }\end{array}$ & Interaction & Interaction & Interaction & $\begin{array}{c}\text { Full } \\
\text { model }\end{array}$ & $\begin{array}{l}\text { Direct } \\
\text { effect }\end{array}$ & $\begin{array}{l}\text { Direct } \\
\text { effect }\end{array}$ & $\begin{array}{l}\text { Direct } \\
\text { effect }\end{array}$ & Interaction & Interaction & Interaction & $\begin{array}{c}\text { Full } \\
\text { model }\end{array}$ \\
\hline \multicolumn{15}{|l|}{ Main effects } \\
\hline $\begin{array}{l}\text { Acquirer } \\
\text { government }\end{array}$ & $-1.522 * * *$ & & & $-6.271 * *$ & & & $-7.653 * * *$ & $2.203 * * *$ & & & -16.55 & & & $17.90^{-}$ \\
\hline & $(0.469)$ & & & $(2.769)$ & & & $(1.258)$ & $(0.683)$ & & & $(0)$ & & & $(1.320)$ \\
\hline $\begin{array}{l}\text { Acquirer } \\
\text { business } \\
\text { group (H2) }\end{array}$ & & -0.668 & & & $-1.493 * *$ & & $-5.623 * * *$ & & -0.258 & & & -0.810 & & $11.43 * * *$ \\
\hline & & $(0.437)$ & & & $(0.643)$ & & $(0.913)$ & & $(0.429)$ & & & $(0.644)$ & & $(1.174)$ \\
\hline $\begin{array}{l}\text { Acquirer } \\
\text { publicly } \\
\text { listed (H3) }\end{array}$ & & & $-1.002 * *$ & & & $-2.507 * * *$ & $-1.774 * *$ & & & $-0.894 * *$ & & & $-3.456 * * *$ & $-2.256^{* *}$ \\
\hline $\begin{array}{l}\text { Interaction } \\
\text { terms }\end{array}$ & & & $(0.407)$ & & & $(0.670)$ & $(0.808)$ & & & $(0.418)$ & & & $(0.878)$ & $(0.911)$ \\
\hline Host country & & & & $-6.366 * *$ & -0.165 & -1.045 & $-8.148 * * *$ & & & & $-15.93 * * *$ & 0.226 & -1.566 & - \\
\hline development & & & & (3.178) & $(0.771)$ & $(0.970)$ & $(1.371)$ & & & & $(1.071)$ & $(0.861)$ & & $\begin{array}{c}18.19 * * * \\
(1.164)\end{array}$ \\
\hline $\begin{array}{l}\text { Acquirer } \\
\text { government } * \\
\text { Host country } \\
\text { development } \\
\text { (H4a) }\end{array}$ & & & & $5.529 * *$ & & & $6.594 * * *$ & & & & $15.46 * * *$ & & & $16.93 * * *$ \\
\hline & & & & $(2.649)$ & & & $(1.354)$ & & & & $(0.925)$ & & & $(1.379)$ \\
\hline $\begin{array}{l}\text { Acquirer } \\
\text { business } \\
\text { group * Host } \\
\text { country } \\
\text { development } \\
\text { (H4b) }\end{array}$ & & & & & $2.012 * *$ & & $5.912 * * *$ & & & & & 1.362 & & $17.24 * * *$ \\
\hline & & & & & $(0.888)$ & & $(1.272)$ & & & & & $(0.854)$ & & $(1.742)$ \\
\hline $\begin{array}{l}\text { Acquirer } \\
\text { publicly }\end{array}$ & & & & & & $2.484 * * *$ & 1.779 & & & & & & $3.646 * * *$ & $2.465 * *$ \\
\hline
\end{tabular}


development

(H4c)

\section{Controls}

\section{Percent}

acquired

Cash

Book/price

Ratio

Market

seeking

Historical
links

Legal

distance

Economic

distance

Foreign

exchange

Year

dummies

Constant

Observations

Log

likelihood

Pseudo R

$-0.0106$

$-0.00569$

(0.827)

(1.092)

$(1.037)$

(1.222)

$\begin{array}{llll}(0.00689) & (0.00645) & (0.00656) & (0.00746)\end{array}$

$\begin{array}{llll}(0.387) & (0.370) & (0.376) & (0.420)\end{array}$

$-0.00728$

$-0.0163^{*}$

$-0.00999$

$-0.00149$

$-0.00323$

$-0.0120$

$-0.00298$

$-0.00345$

$-0.0113$

$\begin{array}{llll}0.0254 * * * & 0.0217 * * * & 0.0211 * * * & 0.0257 * * *\end{array}$

$0.00651)$
-0.433

$(0.00703)$
-0.0651

$(0.00836) \quad(0.00802)$
$-0.601)$

$(0.00639) \quad(0.00657)$
0.0852

(0.00886)

$(0.409)$

$(0.418)$

$-0.601$

$(0.407)$

$(0.362)$

$(0.379)$

0.545

(0.00643)

0.0592

$(0.00686) \quad(0.00909)$
0.413

$0.0267 * * * \quad 0.0351 * * * 0.0395 * 0.022$

$(0.379)$

0.413

0.274

$(0.00833) \quad(0.00646)$

.00648) (0.00861)

$(0.00655)$

(0.00753)

$-0.441$

0.126

0.110

$-0.428$

$-0.0265$

0.377

$0.00807)$

$(0.0236) \quad(0.0$

$0.0440 * *$

$\begin{array}{lll}(0.518) & (0.465) \quad(0.459)\end{array}$

(0.842)

(0.586)

(0.673)

$-0.604$

$-0.444$

0.00641

$0.00633)$

(0.0195)

(0.00646)

$(0.438)$

$0.504)$

$-0.0965$

$-0.321$

$-0.671$

$-0.157$

$-1.499 *$

(0.964) (0.567)$$
0.409
$$

0.0439

$0.00646)$
0.396

$(0.0135) \quad(0.0350)$

$\begin{array}{lll}(0.644) \quad(0.662) \quad(0.644) & -0.974)\end{array}$

$(0.780)$

(0.668)

$-1.064$

(0.448)

(0.469)

(1.043)

0.882

0.255

$-0.56$

$-0.974 \quad-0.605$

$-1.758$

$-1.054$

(0.795)

$-0.725$

$-1.193$

0.764

$(0.573)$

(0.681) (1.223)

$\begin{array}{llll}(1.331) & (1.149) \quad(1.116) \quad(1.672)\end{array}$

(1.446)

$-2.040$

$-1.502$

$(1.109)$

$(0.696)$

(0.763)

(1.420)

$-2.550 *$

$-2.553$

$5.174 \quad 5.221^{*} \quad 5.18$

(3.416) (2.933) (2.871)

3.371

$5.323 * *$

(1.645)

(2.093)

$(1.462)$

$-0.472$

$-0.263$

$-0.421$

$(0.676)$
-0.271

$(1.269)$

$-1.378$

(3.439)

$-0.227$

$\begin{array}{ll}-0.142 & -0.0875\end{array}$

(3.064)

(2.611)

$8.983 * * *$

$8.475^{*}$

4.396

$(1.151)$

(1.121)

(1.686)

(1.462)

(1.732)

$-0.791$

(0.320)

$-0.0451$

$(3.329)$

(4.201)

(4.086) (2.931)

4.568

0.0134

4.585

$10.14^{* *}$

(2.292)

Yes

$(0.554)$

$(0.0532)$

$(0.499)$

$-0.584 *$

$-1.187$

$-0.324$

$(2.958)$
-0.223

(3.454)

(2.796)

(3.758)

$-0.750$

(5.411)

Yes

Yes

(0.327)

$(1.517)$

$(0.387)$

$(1.086)$

$-0.530$

$-4.790 \quad-5.478$

$-5.478-6.143$

6.139

$-5.432 *$

$-9.184 * *$

0.0929

Yes

Yes

Yes

Yes

Yes

Yes

(3.242)

$\begin{array}{llll}(4.591) & (4.044) \quad(3.940)\end{array}$

$\begin{array}{cccc}85 & 85 & 85 & 85 \\ -42.10 & -46.86 & -45.24 & -38.17\end{array}$

(3.264)

$(4.505)$

(6.05

(5.653)

$-6.686 *-7.615$

$12.62 * *$

$-8.024 *$

$-13.51 * * * \quad-3.821$

$-44.33$

$-41.77$

$-27.87$

85

85

(4.168)

(5.604)

$(4.384)$

85

85

(21.77)

0.230

0.275

0.516

0.352

0.166

0.203

0.460

0.187

0.282

0.590 
Table 8a. Generating level of diversification for robustness checks

\begin{tabular}{|l|l|}
\hline Match & Level of diversification \\
\hline All 4 digits of primary SIC codes match & Diversification=0 \\
\hline First 3 digits of primary SIC codes match & Diversification=1 \\
\hline First 2 digits of primary SIC codes match & Diversification=2 \\
\hline First 1 digit of primary SIC codes match & Diversification=3 \\
\hline 0 primary SIC codes match & Diversification $=4$ \\
\hline
\end{tabular}

Table 8b. Level of diversification based on Primary SIC codes

\begin{tabular}{|c|c|c|c|c|}
\hline $\begin{array}{l}\text { Level of } \\
\text { diversification }\end{array}$ & & & Percentage $\%$ & $\begin{array}{l}\text { Cumulative } \\
\text { percentage }\end{array}$ \\
\hline & 0 & 35 & 28 & 28 \\
\hline & 1 & 1 & 0.8 & 28.8 \\
\hline & 2 & 13 & 10.4 & 39.2 \\
\hline & 3 & 12 & 9.6 & 48.8 \\
\hline & 4 & 64 & 51.2 & 100 \\
\hline Total & & 125 & 100 & \\
\hline
\end{tabular}


Table 9. Results for continuous diversification variable using tobit model.

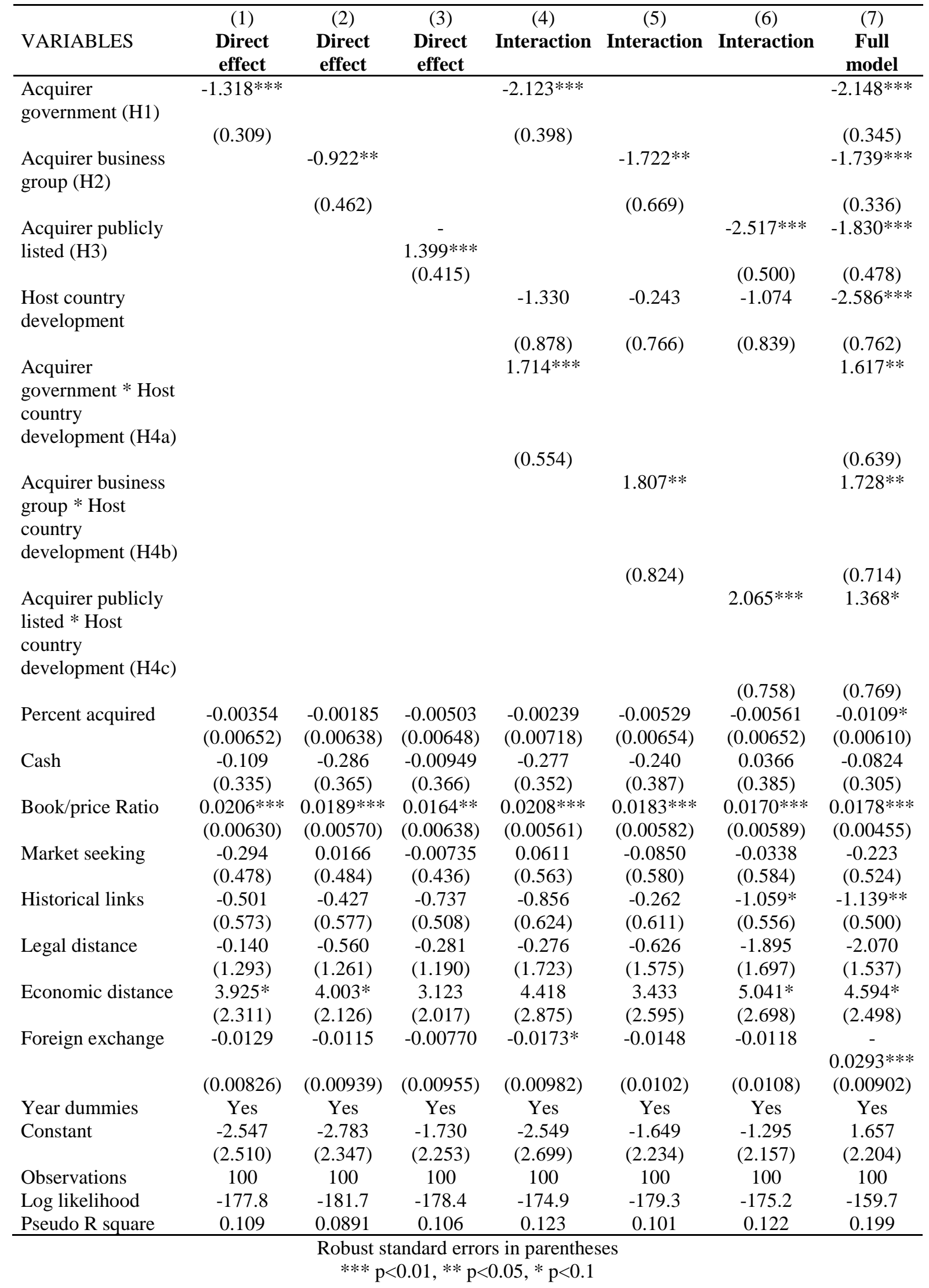

